\title{
Old drugs, old problems: where do we stand in prediction of rheumatoid arthritis responsiveness to methotrexate and other synthetic DMARDs?
}

\author{
Vasco Crispim Romão ${ }^{1,2}$, Helena Canhão ${ }^{1,2}$ and João Eurico Fonseca ${ }^{1,2^{*}}$
}

\begin{abstract}
Methotrexate (MTX) is the central drug in the management of rheumatoid arthritis (RA) and other immune mediated inflammatory diseases. It is widely used either in monotherapy or in association with other synthetic and biologic disease modifying antirheumatic drugs (DMARDs). Although comprehensive clinical experience exists for MTX and synthetic DMARDs, to date it has not been possible to preview correctly whether or not a patient will respond to treatment with these drugs. Predicting response to MTX and other DMARDs would allow the selection of patients based on their likelihood of response, thus enabling individualized therapy and avoiding unnecessary adverse effects and elevated costs. However, studies analyzing this issue have struggled to obtain consistent, replicable results and no factor has yet been recognized to individually distinguish responders from nonresponders at treatment start. Variables possibly influencing drug effectiveness may be disease-, patient- or treatment-related, clinical or biological (genetic and nongenetic). In this review we summarize current evidence on predictors of response to MTX and other synthetic DMARDs, discuss possible causes for the heterogeneity observed and address its translation into daily clinical practice.
\end{abstract}

Keywords: Predictors of response, Rheumatoid arthritis, Synthetic DMARDs, Methotrexate

\footnotetext{
* Correspondence: jecfonseca@gmail.com

'Rheumatology Research Unit, Instituto de Medicina Molecular - Faculdade de Medicina da Universidade de Lisboa, Edifício Egas Moniz - Av. Prof. Egas Moniz, Lisboa 1649-028, Portugal

Full list of author information is available at the end of the article
}

\section{Introduction}

Methotrexate (MTX) is the anchor disease modifying anti-rheumatic drug (DMARD) in the management of rheumatoid arthritis (RA) and other immune mediated chronic inflammatory disorders. In RA, it is the most commonly used DMARD and the first one to be chosen $[1,2]$ due to its efficacy, safety and cost, ultimately translated by the best drug retention rate among DMARDs [3-6]. It is the gold standard in the management of RA and can be prescribed in monotherapy or in combination with other synthetic or biological agents [7-9]. Multinational recommendations have been issued for the use of MTX in RA management [10] and are summarized in Table 1. However, MTX is not effective or induces significant adverse events in a considerable number of patients [11] who are forced to discontinue it and switch to another DMARD regimen, generally with equally heterogeneous responses [5].

Being able to predict response to first-line DMARDs, has been one of the main challenges in RA management for over two decades [12] and it is a good example of the increasingly appealing concept of personalized therapy, that is, choosing the drug of most benefit for a particular patient. This would be of tremendous benefit in several ways. By identifying patients less prone to respond it would avoid needless exposure to potentially toxic drugs and the waste of precious time to achieve disease control, a crucial endpoint to prevent development of structural damage [13]. Likely responders would be maintained with the most appropriate DMARD with more certainty, obviating an early, possibly unnecessary, switch to other potentially less effective DMARDs or to more costly biologicals. Theoretically, this would allow physicians to quit the current trialand-error approach and adopt solid, objective criteria of targeted drug selection, leading to cheaper, quicker, safer and more effective control of the disease.

However, this has proved to be an arduous task and to date there are few clear, reliable, variables that can be 
Table 1 Multinational recommendations for the use of methotrexate in RA.

\begin{tabular}{|c|c|c|c|c|}
\hline \multicolumn{2}{|r|}{ Recommendation } & \multirow{2}{*}{$\begin{array}{l}\text { Level of } \\
\text { evidence }\end{array}$} & \multirow{2}{*}{$\begin{array}{l}\text { Grade of } \\
\text { recommendation } \\
\text { C }\end{array}$} & \multirow{2}{*}{$\begin{array}{l}\begin{array}{l}\text { Selected } \\
\text { references }\end{array} \\
{[39,231-237]}\end{array}$} \\
\hline & $\begin{array}{l}\text { The work-up for patients starting methotrexate should include clinical assessment of risk } \\
\text { factors for methotrexate toxicity (including alcohol intake), patient education, AST, ALT, } \\
\text { albumin, CBC, creatinine, chest } \times \text { ray (obtained within the previous year); consider serology for } \\
\text { HIV, hepatitis B/C, blood fasting glucose, lipid profile and pregnancy test. }\end{array}$ & & & \\
\hline 2 & $\begin{array}{l}\text { Oral methotrexate should be started at } 10 \text { to } 15 \mathrm{mg} / \text { week, with escalation of } 5 \mathrm{mg} \text { every } 2 \text { to } \\
4 \text { weeks up to } 20 \text { to } 30 \mathrm{mg} / \text { week, depending on clinical response and tolerability; parenteral } \\
\text { administration should be considered in the case of inadequate clinical response or } \\
\text { intolerance. }\end{array}$ & $2 b$ & B & [238-242] \\
\hline 3 & $\begin{array}{l}\text { Prescription of at least } 5 \mathrm{mg} \text { folic acid per week with methotrexate therapy is strongly } \\
\text { recommended. }\end{array}$ & $1 a-$ & A & {$[207,243-245]$} \\
\hline 4 & $\begin{array}{l}\text { When starting methotrexate or increasing the dose, ALT with or without AST, creatinine and } \\
\text { CBC should be performed every } 1 \text { to } 1.5 \text { months until a stable dose is reached and every } 1 \text { to } \\
3 \text { months thereafter; clinical assessment for side effects and risk factors should be performed } \\
\text { at each visit. }\end{array}$ & 4 & C & {$[39,233,246-250]$} \\
\hline 5 & $\begin{array}{l}\text { Methotrexate should be stopped if there is a confirmed increase in ALT/AST greater than } \\
\text { three times the ULN, but may be reinstituted at a lower dose following normalization. If the } \\
\text { ALT/AST levels are persistently elevated up to three times the ULN, the dose of methotrexate } \\
\text { should be adjusted; diagnostic procedures should be considered in the case of persistently } \\
\text { elevated ALT/AST more than three times the ULN after discontinuation. }\end{array}$ & $2 b$ & C & {$[237,250-252]$} \\
\hline 6 & Based on its acceptable safety profile, methotrexate is appropriate for long-term use. & $2 b$ & B & {$[253-258]$} \\
\hline 7 & $\begin{array}{l}\text { In DMARD-naive patients the balance of the efficacy/toxicity favors methotrexate } \\
\text { monotherapy over combination with other conventional DMARDs; methotrexate should be } \\
\text { considered as the anchor for combination therapy when methotrexate monotherapy does not } \\
\text { achieve disease control. }\end{array}$ & $1 \mathrm{a}-$ & A & {$[7,57,259-263]$} \\
\hline 8 & $\begin{array}{l}\text { Methotrexate can be safely continued in the perioperative period in RA patients undergoing } \\
\text { elective orthopedic surgery. }\end{array}$ & $1 b$ & B & {$[264,265]$} \\
\hline 9 & $\begin{array}{l}\text { Methotrexate should not be used for at least three months before planned pregnancy for } \\
\text { men and women and should not be used during pregnancy or breast feeding }\end{array}$ & 4 & $C$ & [266-268] \\
\hline
\end{tabular}

Adapted by permission from BMJ Publishing Group Limited. [Ann Rheum Dis, Visser K et al. 2009, 68:1086-1093]. Evidence-based recommendations for the use of methotrexate in daily clinical care of rheumatic disorders, issued by 751 rheumatologists from 17 countries through systematic review of the literature, discussion and voting. Levels of evidence and grades of recommendation were determined according to those established by the Oxford Centre for Evidence Based Medicine [269], as follows: level 1a - systematic review (SR; with homogeneity) of randomized clinical trials (RCTs); level 1b - individual RCT (with narrow confidence interval); level 1c - all or none; level 2a - SR (with homogeneity) of cohort studies; level $2 \mathrm{~b}$ - individual cohort study (including low quality RCT); level 2c - 'outcomes' research, ecological studies; level 3a - SR (with homogeneity) of case-control studies; level 3b - individual case-control study; level 4 - case-series (and poor quality cohort and case-control studies); level 5 - expert opinion without explicit critical appraisal or based on physiology, bench research or 'first principles'; a minus sign (-) can be added to a particular level, to denote that it fails to provide a conclusive answer because of either a single result with a wide confidence interval or a SR with troublesome heterogeneity. Grade of recommendation A - consistent level 1 studies; grade of recommendation B - consistent level 2 or 3 studies or extrapolations from level 1 studies; grade of recommendation C - level 4 studies or extrapolations from level 2 or 3 studies; grade of recommendation D - level 5 evidence or troublingly inconsistent or inconclusive studies of any level. ALT, alanine aminotransferase; AST, aspartate aminotransferase; CBC, complete blood count; DMARD, disease-modifying antirheumatic drug; RA, rheumatoid arthritis; SD, standard deviation; ULN, upper limit of normal.

used in daily practice to allow prediction of response to MTX or other DMARDs [14-19]. While predictors of poor RA prognosis are well established [20,21], they do not accurately correlate with response to treatment [16]. Furthermore, heterogeneous response is most likely the result of multi-factor interactions and cannot be explained by a single cause-effect mechanism within a certain domain. Those factors that are possibly influencing drug effectiveness can be divided into patient-related (age, gender, ethnicity, comorbidities), disease-related (duration, activity, disability, biomarkers), treatmentrelated (compliance, dose, previous drugs) and genetic factors [16]. We conducted a literature review to summarize current available data on predictors of response to MTX and other DMARDs (dividing them into clinical factors, nongenetic biomarkers and genetic biomarkers), discuss the causes for the discrepancies reported and critically analyze the possible translation into clinical practice.

\section{Clinical predictors of response}

Several clinical factors have been studied and it has been difficult to reach a consensus on which factors are undoubtedly predictive of response to treatment with MTX and other DMARDs (Table 2).

Regarding gender, it seems that men respond better to MTX than women: in the systematic review by Drouin et al. [15], the authors found that male gender was associated with a better clinical response to MTX both in early [22] and established RA [23]. Similar conclusions were reached by Anderson et al. in a large meta-analysis of randomized controlled trials (RCTs), including 1,435 patients, in terms of achieving American College of Rheumatology (ACR) 20 responses [24], and by Saevarsdottir and 
Table 2 Summary of clinical predictors of response to MTX and other DMARDs.

\begin{tabular}{|c|c|c|}
\hline Factors & Predictor of response? & Comments \\
\hline Gender & $\begin{array}{l}\text { Yes, men respond better to } \\
\text { MTX }\end{array}$ & Both in early and established RA; not extendable to other DMARDs \\
\hline Age & No & $\begin{array}{l}\text { Strong evidence showing lack of influence on MTX responsiveness, a few contradicting } \\
\text { studies; probably also no influence on other DMARDs }\end{array}$ \\
\hline Ethnicity & Uncertain & Despite the theoretical rationale, more data is needed \\
\hline Smoking & $\begin{array}{l}\text { Likely, active smokers } \\
\text { respond worse to MTX }\end{array}$ & $\begin{array}{l}\text { Most studies do not analyze it; however, available studies point to worse response in } \\
\text { active smokers; not certain as to extension to other DMARDs }\end{array}$ \\
\hline Disease duration & $\begin{array}{l}\text { Yes, better response in } \\
\text { early RA }\end{array}$ & $\begin{array}{l}\text { Early RA has better response than established RA, but no influence of duration in } \\
\text { longstanding disease; controversial results due to methodological heterogeneity }\end{array}$ \\
\hline Prior DMARD use & Yes, worse response & $\begin{array}{l}\text { Previous DMARD use associated with worse response to MTX and other DMARDs; } \\
\text { however, not confirmed in some studies; results likely to be affected by several clinical } \\
\text { confounders }\end{array}$ \\
\hline $\begin{array}{l}\text { Disease activity measured } \\
\text { by composite scores }\end{array}$ & $\begin{array}{l}\text { Yes, worse response if } \\
\text { higher baseline activity }\end{array}$ & $\begin{array}{l}\text { However, frequently not replicable with different scores; unclear which scores are better, } \\
\text { likely to depend on response measures used }\end{array}$ \\
\hline $\begin{array}{l}\text { Disease activity measured } \\
\text { by isolated variables }\end{array}$ & Uncertain & Contradicting findings; unreliable when variables are used separately \\
\hline Disability & Uncertain, not likely & $\begin{array}{l}\text { No association in most studies; inverse relation between HAQ and response in some } \\
\text { early RA studies }\end{array}$ \\
\hline Pain global assessment & No & $\begin{array}{l}\text { Strong evidence showing lack of influence on response to MTX and other DMARDs; a } \\
\text { few contradicting studies }\end{array}$ \\
\hline Concomitant NSAIDs & Uncertain & Only two studies suggesting higher response to MTX in NSAIDs users; more data needed \\
\hline Concomitant corticosteroids & Likely, better response & $\begin{array}{l}\text { Although most studies fail to analyze it, combined therapy with steroids seems to have } \\
\text { better results than DMARD monotherapy }\end{array}$ \\
\hline Radiographic scores & No & $\begin{array}{l}\text { Extensively shown that baseline radiographic scores do not predict clinical response to } \\
\text { any DMARD }\end{array}$ \\
\hline
\end{tabular}

Conclusions and comments are based on the findings reported and discussed in the text. DMARDs, disease modifying anti-rheumatic drugs; HAQ, health assessment questionnaire; MTX, methotrexate; NSAIDs, non-steroidal anti-inflammatory drugs; RA, rheumatoid arthritis.

colleagues [25], in a population of early RA patients (SWEFOT trial), with a worse European League Against Rheumatism (EULAR) response being observed in women (odds ratio $(\mathrm{OR})=0.50,95 \%$ confidence interval $(\mathrm{CI}) 0.31$ to 0.81 ). Stranzl et al. also found female sex to be an independent predictor of poor response to MTX $(\mathrm{OR}=3.3, P=$ 0.009 ) [26]. In the study by Vázquez et al. [27], in early RA patients, male gender was associated with remission after two years of MTX \pm gold treatment in the univariate analysis but not in the multivariate analysis. Hider et al. [14] found no differences between men and women in response rates to MTX in a prospective study of an early inflammatory polyarthritis cohort and there are also other studies that were not able to identify an influence of gender on MTX response [28]. In spite of some conflicting results, it seems that most of the evidence points in the direction of male gender being a predictor of good response to MTX in both early and established RA. Indeed, in a recently published study [29], a predictive model for 24-month remission was developed for patients with early RA treated in a RCT with MTX \pm corticosteroids \pm cyclosporine [30]; it was validated in an early RA cohort (ERAN) of patients treated with MTX or other DMARDs [31]. The authors concluded that one of the three variables that predicted remission at 24 months was male gender $(\mathrm{OR}=3.14$,
$P<0.001)$. As in this latter study, most of the analyses of response to other DMARDs have been done together with MTX, so their individual effect is difficult to predict. Two publications from the 1990s, a meta-analysis [32] and an observational study [33], comprising a significant number of patients, demonstrated that gender did not influence the response to treatment with sulphasalazine (SSZ), gold and penicillamine. A more recent open label trial showed no influence of gender on whether patients with early RA started on hydroxychloroquine (HCQ) would have to step up therapy to MTX [34]. Other studies have also failed to detect a significant effect of gender on treatment response to DMARDs, other than MTX [28,32,35-37]. Overall, it seems that under the light of current evidence it is not possible to generalize the better response to MTX treatment seen in men to other DMARDs. The possible explanation of the influence of gender on MTX responsiveness, as proposed by Hider et al. [16], might be that hormonal factors that influence the pharmacokinetics and pharmacodynamics of each drug contribute to a better or worse response, explaining the apparent discrepancy in the influence of this factor on different DMARDs. Another question could be raised based on the fact that female gender is per se predictive of a worse global prognosis in terms of radiographic progression and disability $[21,38]$ : is the female 
worse response to treatment with MTX contributing to this observation? This is a hypothesis that needs further investigation.

Age does not seem to be a predictive factor of response to MTX or to other DMARDs. Most studies showed a lack of effect of baseline age on clinical response to MTX therapy, including two large meta-analyses [15,39], and, therefore, it does not seem to influence responsiveness [14,23,24,26-28,32,37,40-42]. Despite this strong body of evidence, some studies have contradicting results, such as the SWEFOT trial [25] which showed that older age was associated with a higher likelihood of both EULAR and the clinical disease activity index (CDAI) response to MTX treatment at three to four months $(\mathrm{OR}=1.30,95 \%$ CI 1.11 to 1.51 ) and the study by Ma et al. [29], where older patients ( $>50$ years old), on the contrary, were less likely to be in remission at 24 months after the start of MTX \pm cyclosporine $(\mathrm{OR}=0.97, P=0.014)$. Thus, despite these two early RA studies, where age seemed to influence response to MTX treatment, although in opposite directions, most studies, including large metaanalyses, showed that age is not a predictor of response to MTX. As to other DMARDs, a single study showed that patients responding to SSZ were younger than nonresponders, with no effect of age on the response to penicillamine and gold [33]. All other publications excluded age as an independent predictive marker of response to DMARDs [24,28,34,35,42].

Ethnicity may play a role in predicting response to DMARDs. Genetic differences influencing drug-metabolizing enzymes can contribute to a differential response between ethnic groups [16]. This can have a tremendous impact in either limiting the ability to generalize data from clinical trials to different population groups or choosing the best DMARD for a specific patient based on his/her ancestry. This can be particularly relevant in some European and North American geographical areas, where patients' origins can be very heterogeneous. Helliwell and Ibrahim reported differences in DMARD drug survival, with South Asian patients discontinuing therapy sooner than patients from Northern Europe [43]. Although inefficacy was one of the reasons for drug discontinuation, it was only patient-reported and not objectively measured and it seemed that other factors, such as adverse reactions and different expectations concerning the disease and treatment, may have weighed more than efficacy in the decision to stop treatment. Moreover, some authors found no association between ethnicity and likelihood of response $[44,45]$ and most studies do not analyze its predicting role. Thus, despite the favorable theoretical rationale, ethnicity is currently not a definite predictor of response to MTX and other DMARDs and more data with large populations are needed to clarify its influence on responsiveness.
Smoking has a negative impact on disease outcomes and is associated with higher disease activity [46-49]. In addition to that, smokers seem to respond worse to MTX. Although most studies on treatment response did not analyze this factor, there seems to be a common conclusion in the ones that did: current smokers do respond worse to MTX treatment, at least in early RA. Wessels et al. showed that early RA patients who smoke and are rheumatoid factor (RF)-positive have a worse response to MTX monotherapy (OR $=0.1,95 \%$ CI 0.0 to 0.4 ) [22]. In an early RA cohort, where 873 patients started MTX monotherapy at inclusion, current smoking was independently associated with significantly worse early and late EULAR, disease activity score (DAS) 28 and joint count responses, when adjusted for other clinical, serologic and genetic factors $(\mathrm{OR}=0.60,95 \% \mathrm{CI} 0.39$ to 0.94$)$ [50]. Past smokers' responses did not differ from never-smokers' and number of pack-years smoked was not associated with responsiveness [50]. Data from the SWEFOT trial confirmed these findings on a similar population and current smoking was the strongest predictor of achieving a poor response $(\mathrm{OR}=0.35,95 \% \mathrm{CI} 0.20$ to $0.63)$, according to all response criteria except ACR50 and ACR70 (although a trend for a poor response was observed) [25]. It has also been shown that smokers tend to consume a higher number of DMARDs over time, suggesting that smoking can reduce therapeutic efficacy and that non-smokers are more likely to achieve an ACR response than smokers [51]. As proposed by Saevarsdottir et al., smoking may interfere with the pharmacodynamic and pharmacokinetic properties of the drugs, thus altering responsiveness [50]. Stamp et al. showed that the intracellular levels of some MTX polyglutamates were decreased in smokers [52], suggesting that MTX metabolism is altered which leads to a poor response. Whatever the mechanism, active smoking is an important modifiable factor that seems to be associated with a poor response to MTX. Tobacco discontinuation should be encouraged and considered an important part of the therapeutic approach.

Longer disease duration has been identified by Anderson and colleagues as the most important factor to predict worse response to MTX in the extensive metaanalysis mentioned before [24], and similar findings were reported in other publications, regarding both MTX and other DMARDs $[16,25,32,33,37,53,54]$. However, Hoekstra et al. [23] failed to demonstrate such an association in a RCT comprising 411 patients treated with MTX (although the mean disease duration was lower) and several other studies also did not detect that association with MTX and other DMARDs [14,15,22,27,28,55-57]. It has been widely shown that treatment of early RA yields better results than treatment of established disease [6,58-61] leading to the 'window of opportunity' concept 
[62-64]. Discrepancies in these results might have been induced by evaluations performed mostly in established RA patients, who probably have a more uniform response to MTX, or in early RA populations that have short-term disease and a narrow disease-duration span making it harder to detect differences in response rates. Thus, while it is likely that patients with early disease respond better than those with established RA, disease duration seems to lose its negative influence with long-term progression of disease and this might confound the results of studies addressing this factor.

An additional question is whether the worse response to treatment in established RA patients is a direct consequence of longstanding disease by itself or if it is related to the failure of previous DMARDs, as was previously discussed by Hider et al. in their 2005 review [16]. Despite the existence of a few reports suggesting that previous DMARD use does not affect response to further treatments $[28,55,57]$, most evidence seems to point in the opposite direction. In fact, literature findings include references to a negative effect of previous DMARD use on the response to treatment with MTX and other DMARDs [24], shorter time to DMARD discontinuation in patients who had previously taken MTX [53] and lower drug survival for DMARDs started following previous therapy and late in the course of the disease [65]. Likewise, Lie et al. found that patients who had previously taken other DMARDs had significantly lower response rates to MTX monotherapy [66]. Based on this study, the absence of any past DMARD therapy was identified as one of the predictive factors of a favorable response to MTX monotherapy [15]. Similar findings were reported by Aletaha and colleagues in patients taking consecutive DMARD courses, with the first DMARDs obtaining a greater decrease in $\mathrm{C}$ reactive protein (CRP) than subsequent ones [1]. Another study found that the effectiveness of a particular DMARD was always higher when started after non-steroidal anti-inflammatory drugs (NSAIDs) than after another DMARD [67]. It may be postulated that patients who do not respond to a certain drug might have a globally more severe and less responsive disease, but other mechanisms might explain these observations. As proposed by Hider et al. [16] previous therapies may alter drug kinetics and influence metabolism in such a way that the effectiveness of subsequent drugs can be lowered. However, this hypothesis has not been adequately tested so far.

Disease activity at baseline has been thoroughly investigated as a potential marker of response but globally the results are inconsistent, which can be related to the different clinical instruments and response criteria used in the studies. In fact, disease activity can be assessed by isolated clinical-laboratory variables (CRP, erythrocyte sedimentation rate (ESR)), tender joint count (TJC), swollen joint count (SJC), global assessment of disease activity on a visual analogue scale (VAS) or by composite scores (DAS, DAS28, CDAI, simplified disease activity index (SDAI)) and different criteria are used to define response (EULAR, ACR, DAS/SDAI remission). Thus, it is crucial to consider this information when interpreting literature data. In the meta-analysis by Drouin et al., high disease activity at baseline as measured by DAS or SDAI was identified as a predictor of a weak response to MTX monotherapy [15]. Wessels et al. showed that in an early RA population, high DAS and high SJC were associated with a poor response to MTX monotherapy, defined as achieving a DAS $\leq 2.4$ at 6 months $(\mathrm{OR}=0.1,95 \% \mathrm{CI} 0.0$ to 0.1$)$ [22]. Other factors such as VAS, ESR and CRP did not seem to have an effect on response. In an established RA study, higher disease activity defined by DAS was also related to a decreased likelihood of response to MTX $(\mathrm{OR}=0.53, P<0.001)$ [23]. These results are in accordance with the findings of Aletaha et al., that early RA patients with higher baseline SDAI (but also CDAI and DAS28) were less likely to achieve remission or low disease activity at one year of MTX monotherapy [68]. In this study, it was observed that the association between disease activity and remission at one year was low but significant at baseline and increased greatly in subsequent visits, with SDAI at three months being highly predictive of one-year remission. Similarly, Saevarsdottir and colleagues found that higher DAS28 at the moment of MTX start predicted a lower likelihood of EULAR response (OR $=0.64,95 \%$ CI 0.52 to $0.80)$, despite no significant association being shown for ACR, SDAI or CDAI response criteria [25]. Vázquez et al. demonstrated that in early RA, patients with low to moderate disease activity at baseline (DAS28<5.1) were four times more likely to be in remission (DAS28<2.6) after two years of MTX \pm gold therapy. Two other studies also demonstrated that in patients with recent onset RA treated with MTX, SSZ or both, a lower baseline DAS was predictive of remission at two [69], three and five years [70]. Thus, the literature seems to show that when disease activity is assessed by composite measures, lower activity at baseline predicts better responses to MTX. Despite this, baseline DAS28 was not different between responders and non-responders to MTX monotherapy in other early [14] and established [28,71] RA studies.

When disease activity is determined by isolated laboratory and clinical variables, evidence is much weaker and somewhat inconsistent. Anderson et al. found lower patient, but not physician, global assessment at baseline to be predictive of worse response to MTX and other DMARDs, a result that contradicts the data presented above. Most studies, however, did not find isolated patient/physician global disease assessment to influence response to treatment with MTX $[22,27,29,66,71]$ or other DMARDs [27,29,34,45]. Wessels et al. showed high SJC to 
predict poor response to MTX in early RA [22], a finding not confirmed in established RA [66]. Ma et al. determined that a TJC higher than 5 at baseline decreased the likelihood of achieving DAS remission at 24 months, with no effect observed for SJC [29]. Verstappen et al. identified a lower Thompson joint score [72] at baseline as predictive of remission at 62 months in patients treated with MTX, gold or HCQ [73]. However, SJC and TJC as isolated variables were also shown not to be predictors of response to treatment with MTX and other DMARDs in several studies $[14,24,27,28,34,70,71]$. As a whole, these data suggest that low disease activity defined by isolated clinical variables is probably associated with a better response to treatment, which is in accordance with the above results for composite measures. However, they should not be used as independent response predictors because comprehensive scores, such as DAS or SDAI, are better predictive tools. Similarly, inflammatory markers are sometimes used to assess disease activity but, globally, results are also far from being in consensus. In the metaanalysis by Drouin [15], neither CRP nor ESR were predictors of response to MTX monotherapy. These conclusions were based on two studies, one of them identifying high ESR to be associated with a worse response in established RA [66] but the other, regarding early RA, only finding this association in the univariate analysis [22]; both showed no effect of CRP. Other studies regarding therapy with MTX \pm other DMARDs did not show any effect of ESR and/or CRP on response to treatment [14,24,26-29, $70,71]$. On the other hand, the study by Combe et al. identified ESR and CRP as two of the five independent predictive factors of disability at five years in early RA patients treated mainly with MTX and SSZ [42]. As to other DMARDs, Matteson et al. found that ESR did not influence response to HCQ monotherapy [34] but in another study a low baseline CRP was the only predictor of a favorable response to HCQ monotherapy in early RA patients $(\mathrm{OR}(\mathrm{CRP} \leq 10 \mathrm{mg} / \mathrm{L})=3.6,95 \% \mathrm{CI} 2.2$ to 6.0$)$ [35]. van Roon and colleagues identified ESR $<35 \mathrm{~mm} \cdot \mathrm{h}^{-1}$ at treatment start to predict higher leflunomide survival (hazard ratio $(\mathrm{HR})=1.38,95 \%$ CI 1.01 to 1.88 ) [36] and likewise, high ESR at disease onset and at DMARD initiation predicted early discontinuation of treatment in an established RA study ( $\mathrm{HR}=1.05$ per $10 \mathrm{~mm} \cdot \mathrm{h}^{-1}$ increase, 95\% CI 1.02 to 1.08) [53]. Contrary to these findings, Capell et al. observed that a lower ESR was related to a worse response to gold, penicillamine or SSZ [32]. As a whole, these results are not sufficient to state whether ESR or CRP alone are predictive factors of response to MTX and other DMARDs. While some studies showed a significant association between inflammatory markers and response, usually with higher baseline values associated with weaker treatment responses, others, including large meta-analyses, do not find these variables to be good predictive markers, at least when considered independently. In the light of current evidence, for the purpose of predicting DMARD response, it is probably better to integrate ESR and CRP components as part of disease activity scores and not judge them individually.

Disease severity and disability at baseline were also proposed by some authors as being predictive of treatment response. Anderson et al. identified a lower functional status, according to the Steinbrocker criteria, to be associated with a weak response to MTX and other DMARDs [24]. In two early RA studies, patients treated with MTX, SSZ or both were more likely to be in remission (DAS < 1.6) at two [69] or three years [70], if they had a low baseline health assessment questionnaire (HAQ) score. Similarly, in other early RA studies, a high HAQ at baseline predicted a poorer response to MTX monotherapy [22,25,45] and to a combination with HCQ [45], with HAQ being the only significant predictor of remission, using all remission definitions, in the paper by Saevarsdottir et al. $(\mathrm{OR}=$ $0.56,95 \%$ CI 0.40 to 0.80 ) [25]. However, several studies showed contradictory results, with baseline HAQ not being an independent predictor of responsiveness to MTX $[14,27-29,66,71,74]$ and other DMARDs [27,28,34,35,74]. While some studies seem to suggest that a higher HAQ predicts a weaker response to MTX and other DMARDs, several other studies with similar populations did not confirm this association.

Pain score was not identified as a predictor of clinical response to MTX monotherapy in the review by Drouin et al. [15] but, contrarily, Goetz and colleagues concluded that a higher baseline pain score was associated with poor response to therapy [75]. In fact, while some studies identified high pain scores to be associated with lower four-year remission rates after treatment with MTX, gold or HCQ [73] and lower responsiveness to HCQ [34], most authors were not able to define baseline pain as an independent predictor of clinical response to MTX $[22,24,27,29,45,66,69-71]$ and other DMARDs $[24,27,35,69,70]$, either in early or established RA. Thus, it seems that evidence suggests that baseline pain scores are not independent predictors of response to DMARD treatment.

Other factors have been studied and there are scattered reports proposing them as possible predictors of response. Concomitant NSAIDs use was associated with an increased efficacy of MTX monotherapy in established RA [23] and a similar significant but weak association was seen in early $\mathrm{RA}(\mathrm{OR}=1.31,95 \% \mathrm{CI} 0.84$ to 2.06$)$ [25]. Most studies did not analyze the effect of NSAIDs and so, given the small amount of evidence, further studies are needed to confirm this association, although a beneficial effect may be expected. Results on concomitant corticosteroid therapy are more difficult to interpret because of different doses and timings for starting 
steroids (before DMARD therapy, during, or both). Saevarsdottir and colleagues found that early RA patients who were already on stable low-dose prednisolone at the start of MTX responded better (OR $=2.84,95 \%$ CI 1.43 to 5.63) [25] and Hider et al. showed that absence of steroid use predicted MTX inefficacy at two years, but not at one year [14]. These results are in accordance with trials that showed that patients treated with combination therapies including steroids have better responses than those on DMARD monotherapy [76-79], even though in these studies steroids and DMARDs were started simultaneously. However, other studies found no association between corticosteroid use and DMARD response $[24,34]$. Despite these latter observations it seems likely that patients on corticosteroid concomitant treatment are more likely to respond to DMARD therapy. Erosion and radiographic scores at baseline do not seem to be reliable predictors of treatment response to DMARDs as was shown in several reports $[27,29,35,45,53,69,73,74]$.

\section{Nongenetic biomarkers of response}

Among nongenetic biomarkers, autoantibodies are probably the most important and most studied (Table 3). In fact, RF and anti-citrullinated protein antibodies (ACPA) are important markers with diagnostic and prognostic roles in RA and were both included in the 2010 RA classification criteria [80]. RF is associated with persistent disease and radiographic progression [21,81-83] but its role in predicting response to treatment is less clear. A large number of studies, comprising a considerable number of patients, showed that RF status does not predict response to MTX and other DMARDs in both early and established RA [1,14,23,25,27-29,34,36,37,42,45,53,55,66,84]. However, in the study by Wessels et al. [22] RF-positivity alone presented a trend towards worse response to MTX monotherapy in early RA patients; RF-positive smokers were definitely worse responders. Similarly, in a retrospective study with 265 patients, Morgan and colleagues found that resistance to three or more DMARDs was more frequent in RF-positive patients (OR $=2.15,95 \%$ CI 1.00 to 4.62) [85]. Verstappen et al. found RF-negativity to be associated with four-year remission in early RA patients started on HCQ, MTX or gold $(\beta=1.63 ; P=0.061)$ [73]. Some authors found RF-positivity to be associated with lower remission rates [70,81,86-89]. However, these studies analyzed remission as an outcome and, thus, these results were more likely to be directly related to the role of RF as a marker of more persistent and severe disease, and not necessarily linked to treatment effectiveness. Overall, most of the available evidence seems to show that baseline RF status does not influence the effectiveness of DMARDs.

The presence and levels of ACPA are currently very important in the diagnosis and prognosis of RA. Diagnostically, they are highly specific (higher than RF) and have a good sensitivity (equal or slightly lower than RF) [90-92]. In terms of prognosis they are associated with worse functional status $[93,94]$, higher disease activity [95,96], severe radiographic progression [13,97-104] and worse disease course [104-106]. Data are much scarcer than with RF, but two early RA studies ( $\mathrm{n}=205$ and $n=405$, respectively) showed that ACPA did not influence MTX effectiveness [22,25]. The study by Cao et al. also found no differences in second-line DMARD response between ACPA-positive and ACPA-negative patients from an early RA cohort that had previously failed first-line DMARD therapy [107]. Likewise, Hodkinson et al. [45], Verschueren et al. [108], Vázquez et al. [27], Boire et al. [109], da Mota et al. [84] and Gossec et al. [70] found no association between ACPA status and the likelihood of achieving low disease

Table 3 Summary of nongenetic biomarkers of response to MTX and other DMARDs.

\begin{tabular}{|c|c|c|}
\hline Factors & $\begin{array}{l}\text { Predictors of } \\
\text { response?k }\end{array}$ & Comments \\
\hline RF & No & $\begin{array}{l}\text { Some results confounded by its poor prognostic role; however, most evidence is clear in that it does not } \\
\text { influence treatment response }\end{array}$ \\
\hline ACPA & Not likely & $\begin{array}{l}\text { More data needed but does not seem to predict response; associated with worse outcomes in some studies } \\
\text { but may reflect more severe disease; interesting reports in UA, pending confirmation }\end{array}$ \\
\hline Anti-MCV & Unknown & Suggested to relate to more severe disease; not yet addressed in terms of response to treatment \\
\hline $\begin{array}{l}\text { Creatinine } \\
\text { clearance }\end{array}$ & No & Few studies analyzed this factor, no association with MTX response in a meta-analysis \\
\hline Hb levels & Uncertain & $\begin{array}{l}\text { Anecdotal reports of association with better response; needs confirmation and its role should be clarified in } \\
\text { future studies }\end{array}$ \\
\hline Cytokines & Uncertain & $\begin{array}{l}\text { Small/pilot studies suggesting association with response; potential promising role of baseline TNF levels, } \\
\text { TNFID }_{50} \text { and IL-1ra/IL-1 } \beta \text { ratio }\end{array}$ \\
\hline Others & Uncertain & $\begin{array}{l}\text { Other interesting factors analyzed in small studies and not further confirmed include MMP-3, urinary } 7-\mathrm{OH}- \\
\text { MTX and IgG hypogalactosylation }\end{array}$ \\
\hline
\end{tabular}

Conclusions and comments are based on the findings reported and discussed in the text. ACPA, anti-citrullinated protein antibodies; anti-MCV, anti-modified citrullinated vimentin antibodies; DMARDs, disease modifying anti-rheumatic drugs; Hb, hemoglobin; IgG, immunoglobulin G; IL-1 ra, interleukin-1 receptor antagonist; IL-1 $\beta$, interleukin-1 $\beta$; MMP-3, matrix metalloproteinase-3; MTX, methotrexate; RF, rheumatoid factor; TNF, tumor necrosis factor; TNFID 50 , dose required to suppress by $50 \%$ the production of tumor necrosis factor; UA, undifferentiated arthritis; 7-OH-MTX, 7-hydroxy-methotrexate. 
activity or remission at $1,2,2.5,3$ or 5 years in DMARD-naïve early RA patients treated with MTX and/or other DMARDs. A recent subanalysis at 8-years follow-up of the BeSt study $(\mathrm{n}=484)$ specifically addressed the association of ACPA with treatment response. The analysis of all treatment groups as a whole, including one arm starting with infliximab [110], showed that ACPA-positive patients responded as well as those who were ACPA-negative, with similar decreases in disease activity, remission rates and functional ability, although they had worse radiographic progression and were less likely to maintain drug-free remission. This last finding was reproduced by other authors who found ACPA positivity to be associated with inability to maintain drug-free remission for more than one [111] or five years [93]. However, there are some contradicting results. In a study comprising 124 Japanese patients treated with MTX or SSZ within one year of disease onset, ACPA positivity was strongly associated with resistance to treatment $(\mathrm{OR}=6.31, P=0.027)$, but the criteria used to define non-responders (starting antitumor necrosis factor (TNF) agents during two years of follow-up) was different from other studies and this must be taken into account [112]. Verstappen et al. [113] recently found the presence of ACPA to be strongly associated with initiation of biological therapy in an early inflammatory polyarthritis population, although this was not directly linked to failure of initial DMARD therapy and may represent the effect of a more severe disease that will require more aggressive therapy. On the other hand, there are some studies that identified an association of ACPA with decreased likelihood of achieving remission at two [87] or eight years [89] in recent onset RA. Other studies have also found a lower response to treatment in ACPA-positive patients, in terms of the magnitude of decrease in DAS28, ESR, CRP and other clinical variables $[102,105,114]$. This may be just a reflection of the higher disease activity that characterizes ACPA-positive disease and it is difficult to state with certainty that it represents a worse response to the treatment instituted. Another issue raised by van Dongen et al. [115] and already reported by others [19] concerns the beneficial effect of MTX in delaying the progression to RA in ACPA-positive undifferentiated arthritis (UA) but not in ACPA-negative UA. This would suggest a favorable effect of ACPA in terms of response to therapy, but the follow-up analysis showed that in ACPA-positive patients, non-responders had higher pretreatment ACPA levels, a finding confirmed in a similar population of patients from the BeSt study [116]. Although the number of patients was small, these results would suggest that while MTX is more effective in UA patients who are ACPA-positive and, thus, probably at a higher risk of developing RA, the titer of this antibody is inversely related to the response to MTX. Larger studies are needed to confirm this potential effect. Overall, evidence does not support the role of ACPA as predictive markers of response to MTX and other DMARDs. Despite some opposite results in terms of remission and response to treatment, the strong prognostic value of this marker associated with worse disease outcomes must be taken into account when analyzing the results and can sometimes disturb the distinction between poor response to treatment and poor prognosis per se. Interesting findings on UA need further confirmation with larger populations and, as suggested by Visser et al. [116], pretreatment ACPA levels should be obtained in studies analyzing response to treatment.

The evidence presented above for ACPA was based on studies using the most common assay, the second-generation anti-cyclic citrullinated peptide (anti-CCP2). Recently, another test targeting modified citrullinated vimentin (anti-MCV) was developed to identify a particular member of the ACPA family [117]. While its current role is not clearly defined in RA, it seems to be as good as anti-CCP2 as a diagnostic marker, with sensitivity and specificity of $62 \%$ to $84 \%$ and $83 \%$ to $95 \%$, respectively, being reported in the literature [118-122]. However, in terms of prognosis there are contradicting results. Anti-MCV was associated with more severe and erosive disease in some studies [109,120,123,124], with a clear correlation with disease activity. In this case, high anti-MCV levels could relate to more active disease and possibly lower response to treatment. However, neither this association $[119,122,125-128]$ nor this correlation was observed by other authors [126-128] and to our knowledge, the impact of anti-MCV status on response to DMARD treatment was not specifically addressed in the studies published to date. It would be of interest to further analyze the role of this antibody as a potential predictive marker of response in future investigations.

Other biomarkers have been studied as potential predictors of response to treatment. ESR and CRP have been discussed earlier, as markers of disease activity.

Creatinine clearance was inversely related to MTX efficacy in one established RA study [23] but the association was weak (OR $=0.99,95 \%$ CI 0.98 to 1.0$)$ and no statistically significant difference was observed in other studies [22], including a meta-analysis evaluating 11 RCT $(n=496)$ that specifically addressed the influence of renal function (and age) on MTX responsiveness [39]. Serum creatinine levels were also demonstrated to be non-predictors of leflunomide treatment survival [36] but data on other DMARDs are even scarcer. High hemoglobin levels were associated with remission (DAS28 <2.6) at two years in the univariate analysis in early RA, DMARD-naïve patients. However, it was not an independent predictor of remission when assessed by 
multivariate logistic regression analysis [27]. In a recent study with a similar population, high hemoglobin levels independently predicted a low disease activity state (SDAI <12) after two years of therapy with MTX \pm SSZ \pm chloroquine sulfate [45]. Although most studies regarding treatment response do not analyze the role of baseline hemoglobin levels as a potential predictive marker, it is known that persistent inflammation can lead to anemia, particularly through the action of IL-6 [129], and low hemoglobin levels have been associated with more active and severe RA [130]. Thus, while hemoglobin concentration may constitute an indirect marker of disease activity, caution is required when interpreting response to treatment, because the suggested association of high hemoglobin and a low disease activity at follow up may simply reflect a milder disease, with less inflammation, lower activity scores and not necessarily a true correlation with better DMARD effectiveness. Nevertheless, as a simple, cheap and widely available laboratory variable, it would be interesting if upcoming studies analyzing treatment response include hemoglobin levels and further investigate whether it may play a true role as a predictive marker.

Being involved in the pathogenesis of RA [131], cytokines are also influenced by MTX and other DMARDs $[132,133]$. Therefore, they are an appealing potential biomarker of response to treatment and have been evaluated in some studies. Baseline serum concentration of TNF was inversely associated with six-month response to MTX and other DMARDs, and levels below $20.1 \mathrm{pg} / \mathrm{mL}$ could independently predict responders with high specificity and sensitivity, in a small sample of both early and established RA patients $(n=38)$ [28]. No effect was seen regarding IL-1 $\beta$, IL-6, IL-8, IL-10 and IL-12. However, in a study of 50 consecutive established RA patients who had already failed one to three DMARDs, pretreatment serum TNF and IL-1 $\beta$ levels were undetectable in the majority of patients and did not predict response to treatment; neither did serum levels of IL-1 receptor antagonist (IL-1ra) or soluble TNF receptor (sTNFR) p55 [134]. In this study, though, a significant association was seen between a low IL-1ra/IL-1 $\beta$ synthesis ratio of unstimulated pretreatment peripheral blood mononuclear cells (PBMC) and good/excellent responses to MTX: an IL-1Ra/IL-1 $\beta$ ratio lower than 100 strongly predicted an ACR response higher than ACR50 $(P<0.0001)$, with positive and negative predictive values of $94 \%$ and $91 \%$, respectively [134]. It has also been demonstrated that baseline IL-10 production by PBMC was higher in MTX responders than in non-responders [135]. Another study comprising a reduced number of early RA patients $(\mathrm{n}=$ 8) reported a correlation between a higher baseline percentage of IL-4 positive CD4+ T cells and low disease activity at six to nine months of MTX treatment [136], a finding in line with other data suggesting a relationship between a low IFN-/IL-4 ratio and better nine-month response to HCQ and SSZ [137]. Low pretreatment levels of soluble IL-2 receptor (sIL-2R, $<442 \mathrm{U} / \mathrm{mL}$ ), translating reduced $\mathrm{T}$-cell activation, predicted six-month remission in early RA patients treated with SSZ monotherapy [138], an association not confirmed in patients with established disease treated with MTX (mean disease duration $>10$ years) [139] or SSZ/gold (mean disease duration $>5$ years) [140]. A small study reported that in 14 early RA patients treated with $\mathrm{HCQ}$, soluble CD30 (sCD30) basal levels were higher in responders than in non-responders $(P<0.03)$, which might be related to a higher activity of Th0/Th2 anti-inflammatory cells [141]. This was not confirmed in a study of 92 RA and UA patients treated with MTX and other DMARDs, where baseline SCD30 levels did not associate with treatment response at one year [142]. In a pilot experimental study $(n=25)$, the MTX-induced in vitro inhibition of T-cell cytokine production was studied and a strong negative correlation was found between clinical response at four months and the dose required to suppress by $50 \%$ the production of TNF (ID $50, r=-0.62, P<0.01)$ [143]. Patients with a TNFID $_{50}$ lower than $224 \mathrm{ng} / \mathrm{mL}$ had a significantly greater reduction in DAS28 after four months of MTX treatment than those with a value above this cutoff $(P<0.02)$, which had a sensitivity of $93 \%$ and a specificity of $86 \%$ for predicting patients with a moderate EULAR response. Since the effect was so pronounced, in vitro suppression of TNF is an interesting assay that may predict response to MTX and guide individual therapeutic decisions; to date and to our knowledge, validation in a larger cohort is pending. As a whole, the data concerning cytokines confirm their potential as predictors of treatment response. Despite the elevated cost associated with most of these assays, they may enable individualized therapy in RA patients if clear associations are confirmed in other, larger, studies.

Reports concerning other biological markers are available but no definite conclusions can be taken regarding their true role as predictive markers, because most studies were pilot studies, based on small samples and their findings were not further validated. These include hypogalactosylation of IgG [144], serum matrix metalloproteinase-3 (MMP-3) levels [145,146], urinary levels of the less effective MTX catabolite, 7-hydroxy-MTX [147], red blood cell (RBC) levels of MTX polyglutamates (MTX PG), the active anti-inflammatory metabolites of MTX [148-152] and synovial vascularity [153].

\section{Genetic biomarkers of response}

Pharmacogenetics may provide an objective explanation for the discrepancies observed in response to DMARDs among patients: the genetic characteristics of each 
patient might interact with a certain drug, interfere with its pharmacokinetics or target, thus affecting its pharmacological action and ultimately leading to different effects. Intense efforts have been focused on the pursuit of polymorphisms and genetic patterns that associate with increased or decreased drug response and the major findings are summarized in Table 4.

$H L A-D R B 1$ shared epitope (SE) alleles are well-established risk factors for RA [154,155] and are associated with more severe and erosive disease [156-159]. However, their influence on DMARD effectiveness is not clear despite several studies that have tried to approach this question. O'Dell et al. showed that SE-positive patients, who had previously failed one DMARD, were much more likely to obtain ACR50 responses if they were on combination treatment (MTX plus SSZ plus HCQ) compared to MTX monotherapy (94\% and 32\% responders, respectively; $P<0.01$ ), with no difference being seen in patients who were SE-negative $(n=84)$ [55]. Additionally, patients on MTX monotherapy responded better if they were SE-negative ( $83 \%$ and $32 \%$, respectively, $P<0.04$ ), an effect that was lost in the combination treatment group. Similarly, Ferraccioli and colleagues demonstrated that, at six months, HLA-DR 0401-positive patients responded worse to MTX monotherapy (29\% and $80 \%$ responders, respectively) and better to cyclosporine (52\% and $5.8 \%$, respectively) than those who were $H L A-D R$ 0401-negative [160]. Hider et al. studied 309 patients from an inception cohort with inflammatory polyarthritis and found that the possession of the $H L A-D R B 1$ SE was the only factor predicting MTX monotherapy inefficacy at one and two years, with a strong association (adjusted $\mathrm{OR}=5.88$ and 3.04 , respectively, both $P=0.02$ ). In the recent Japanese study mentioned above [112], early RA patients carrying one or two copies of the SE-positive $H L A-D R B 1$ *04 allele (especially *0405) were more likely to be resistant to DMARD therapy (predominantly MTX) at two years (OR $=2.89, P=0.011$ ), an effect not seen with other SE-positive alleles. In line with these findings, González-Gay et al. previously reported that patients positive for SE alleles were significantly more likely to be treated with cyclosporine A, because of insufficient response to MTX or MTX plus chloroquine $(\mathrm{OR}=2.9, P=0.006)$; the strongest risk for requiring cyclosporine A treatment was seen with the HLA-DRB1*0401/*0404 genotype [161]. Yet, in a Pakistani population of 91 RA patients, the only SE allele associated with response to treatment was $H L A-D R B 1 * 03$, significantly more common in non-responders, with no effect being observed in other alleles, including $D R B 1 * 04$ and $D R B 1 * 01$ [162]. As a whole, these studies indicate that SEpositive patients may respond worse to MTX and that the $H L A-D R B 1 * 04$ allele (and maybe also $H L A-D R B 1 * 03$ ) plays an important role in this effect. However, several authors failed to show an association between SE-status and induction $[27,37,70]$ or persistence [163] of remission in patients treated with MTX and other DMARDs, while

Table 4 Summary of genetic biomarkers of response to MTX and other DMARDs.

\begin{tabular}{|c|c|c|}
\hline Factors & $\begin{array}{l}\text { Predictors of } \\
\text { response? }\end{array}$ & Comments \\
\hline$\overline{\mathrm{SE}}$ & $\begin{array}{l}\text { Yes, worse response } \\
\text { to MTX }\end{array}$ & $\begin{array}{l}\text { SE-positive patients seem to respond worse to MTX, especially carriers of the HLA-DRB1*04 allele; } \\
\text { association with remission controversial; not extendable to other DMARDs }\end{array}$ \\
\hline RFC1 & $\begin{array}{l}\text { Likely, better } \\
\text { response to MTX }\end{array}$ & $\begin{array}{l}\text { 80G>A: evidence suggests favorable response in variant allele carriers, although some studies did not } \\
\text { confirm it; other identified SNPs may have a role and explain discrepancies }\end{array}$ \\
\hline$A B C B 1$ & Uncertain & 3435C>T: several studies suggesting association with better response, not confirmed in others \\
\hline$A B C C 1-4 / A B C G 2$ & Unknown & Not thoroughly studied \\
\hline GGH & Uncertain & Conflicting results regarding SNPs $401 \mathrm{C}>\mathrm{T}, 452 \mathrm{C}>\mathrm{T}$ and $16 \mathrm{~T}>\mathrm{C}$ \\
\hline FPGS & Uncertain & $\begin{array}{l}\text { Few studies; contradicting findings with SNP 14G>A, no association of } 14 G>A \text { with response in two } \\
\text { studies }\end{array}$ \\
\hline \multirow[t]{2}{*}{ TYMS } & Uncertain & $\begin{array}{l}\text { TSER }{ }^{*} R /{ }^{*} R \text { : opposite results suggesting better responses for both } 2 R / 2 R \text { and } 3 R / 3 R \text { and others showing } \\
\text { no effect }\end{array}$ \\
\hline & & 6 bp-del: favorable role suggested, but not found in other studies \\
\hline DHFR & Uncertain & $\begin{array}{l}\text { Several SNPs described but addressed in single studies; } 317 \mathrm{~A}>\mathrm{G} \text { was the only one associated with } \\
\text { response but only when using rDAS28 and with marginal effect }\end{array}$ \\
\hline ATIC & Uncertain & $\begin{array}{l}347 C>G \text { is the most studied, but conflicting results did not allow a definition of its role; other SNPs have } \\
\text { been identified and associated with response in a few studies but lack replication }\end{array}$ \\
\hline MTHFR & No & $\begin{array}{l}677 C>T \text { and } 1298 \text { A >C have been extensively studied and two large meta-analysis found no association } \\
\text { with MTX effectiveness }\end{array}$ \\
\hline $\begin{array}{l}\text { Polygenic } \\
\text { combinations }\end{array}$ & $\begin{array}{l}\text { Uncertain, but } \\
\text { promising }\end{array}$ & Several reports of SNPs combinations associated with response, but lacking replication \\
\hline
\end{tabular}


others found the absence of SE alleles to be associated with DMARD-free remission [111] or remission to be more likely in patients with $\leq 1 \mathrm{SE}$-allele [86]. Few studies have analyzed other DMARDs in monotherapy regimens $[34,164]$. Globally, SE seems to influence response to DMARD treatment, with an apparent negative effect on MTX response, and further studies analyzing predictors of response should include this genetic marker in order to clarify its true influence on drug effectiveness.

Figure 1 illustrates the MTX cellular pathway and mode of action. Single nucleotide polymorphisms (SNPs) in genes codifying proteins involved in this process have been identified and thoroughly studied for their influence on the response to MTX.

Regarding membrane transporters, reduced folate carrier 1 (RFC1) 80G > A may influence influx of MTX into the cell, but its influence on drug responsiveness is not clear. It has been reported that patients with the RFC1 80A/A genotype have a greater response to MTX (based on several disease activity measurements) than wild-type 80G/G patients: lower global VAS [165], lower SJC and disease activity VAS [149], better EULAR responses [166] and a 3.32 -fold higher probability of achieving remission $(P=$ $0.021, \mathrm{n}=174)$, with statistically significant differences in the A allele prevalence between good and poor responders (62.1\% and $47.8 \%$, respectively, $P=0.013$ ) [167]. Other relevant findings include higher RBC MTX PG levels in AA homozygous RA patients compared to other genotypes $(P=0.007)[168]$, higher MTX plasma levels in AA children with acute lymphoblastic leukemia $(P=0.004)$ [169] and lower uptake of MTX in CD4+ T cells and B cells in healthy individuals expressing the GG genotype, compared to those having the A allele [170]. These arguments seem to support a favorable role for the RFC1 $80 \mathrm{G}>\mathrm{A}$ SNP as a predictor of good response to MTX, but other authors have failed to confirm its association with MTX efficacy [150,152,171-173]. Caution must be taken regarding interpretation of RBC MTX PG levels, because currently it is not absolutely certain that they represent the actual concentration of these metabolites inside other important cells in RA such as leucocytes or synovial cells [174]. Furthermore, a recent study identified six other SNPs in the RFC1 gene associated with poor response to MTX, which contributes to the hypothesis that other polymorphisms in this gene may also affect the response to MTX, thus providing an explanation for the contradictory results in some of the studies [173].

ATP-binding cassette $(A B C) B 1(A B C B 1)$ codifies Pglycoprotein, a cell membrane-associated transporter of several drugs. Its influence on MTX efflux is unclear $[175,176]$. Nevertheless, the effect of $A B C B 1$ SNPs has been studied, particularly that of $3435 \mathrm{C}>\mathrm{T}$. Pawlik et al. showed that patients with the $3435 \mathrm{TT}$ genotype were 2.89 times more likely to respond to MTX than those carrying one or two $C$ alleles $(n=92)$ [177] and, likewise, Drozdzik and colleagues found a 4.65-fold higher probability of symptom remission in $\mathrm{TT}$-positive patients, compared to those with the CC genotype ( $\mathrm{n}=$ $174, P=0.003)$ [178]. A recent study also reported lower mean DAS28 in 3435TT patients compared to the 3435CC genotype $(P=0.02)$ [152]. On the other hand, an Asian study found that patients with the 3435TT SNP were nonresponders more frequently than patients with the $3435 \mathrm{CC}$ genotype (adjusted $\mathrm{OR}=8.78, P=$ 0.038) [172]. However, these differences may be related to the response criteria applied, which in this study were based on MTX maintenance dose (responders if dose was below $6 \mathrm{mg} /$ week, nonresponders if MTX dose was above $6 \mathrm{mg} /$ week) and not directly on the evolution of symptoms or disease activity. Additionally, other authors found no association between $A B C B 13435 \mathrm{C}>\mathrm{T}$ and MTX efficacy $[179,180]$. Despite the description of frequent SNPs in other transport proteins involved in the efflux of MTX from the cell, such as ABCC1-4 and ABCG2 [181], they have not been thoroughly addressed regarding $\mathrm{MTX}$ effectiveness in $\mathrm{RA}$; there are some reports of better response to MTX in psoriasis patients carrying SNPs for $A B C C 1$ and $A B C G 2$ [182] but recently three SNPs in $A B C C 2$ and $A B C G 2$ genes were not related to MTX response [152] and further studies are needed to clarify their true influence.

As to the enzymes involved in the glutamation cycle of MTX inside the cell, $\boldsymbol{\gamma}$-glutamyl hydrolase (GGH) is the most studied one. The SNP 401C>T of the promoter region of GGH was shown to influence MTX PG levels, which were lower in patients carrying the TT genotype compared to those with one or two $\mathrm{C}$ alleles $(\mathrm{OR}=4.8$, $P=0.002$ ) [168]. However, the same group of researchers did not find any effect of this SNP on response rates to MTX in a prospective longitudinal study $(n=48)$ [150]. Other SNPs in GGH include $452 \mathrm{C}>\mathrm{T}$, that has been associated with decreased enzyme activity and accumulation of intracellular MTX PG [183], but was found not to influence MTX efficacy [152,173,184]. The role of folylpolyglutamate synthetase (FPGS) has been less studied. Although its expression in PBMC has been associated with poor response to MTX [26], an unexpected result given the role it is thought to have in converting MTX to its active form, the SNPs of the FPGS gene identified so far are of unclear functional and clinical significance [176]. Two studies failed to demonstrate an association between the SNPs $14 \mathrm{G}>\mathrm{A}$ and 1994A $>\mathrm{G}$ and MTX response [173,184], but Sharma et al. showed that carriers of the A allele of the $14 \mathrm{G}>\mathrm{A}$ SNP responded worse $(\mathrm{OR}=3.47,95 \% \mathrm{CI} 1.19$ to 10.12) [185]. Thus, more data is needed to evaluate its influence on drug responsiveness.

MTX PG inhibit several enzymes, including thymidylate synthase (TYMS), dihydrofolate reductase (DHFR), 


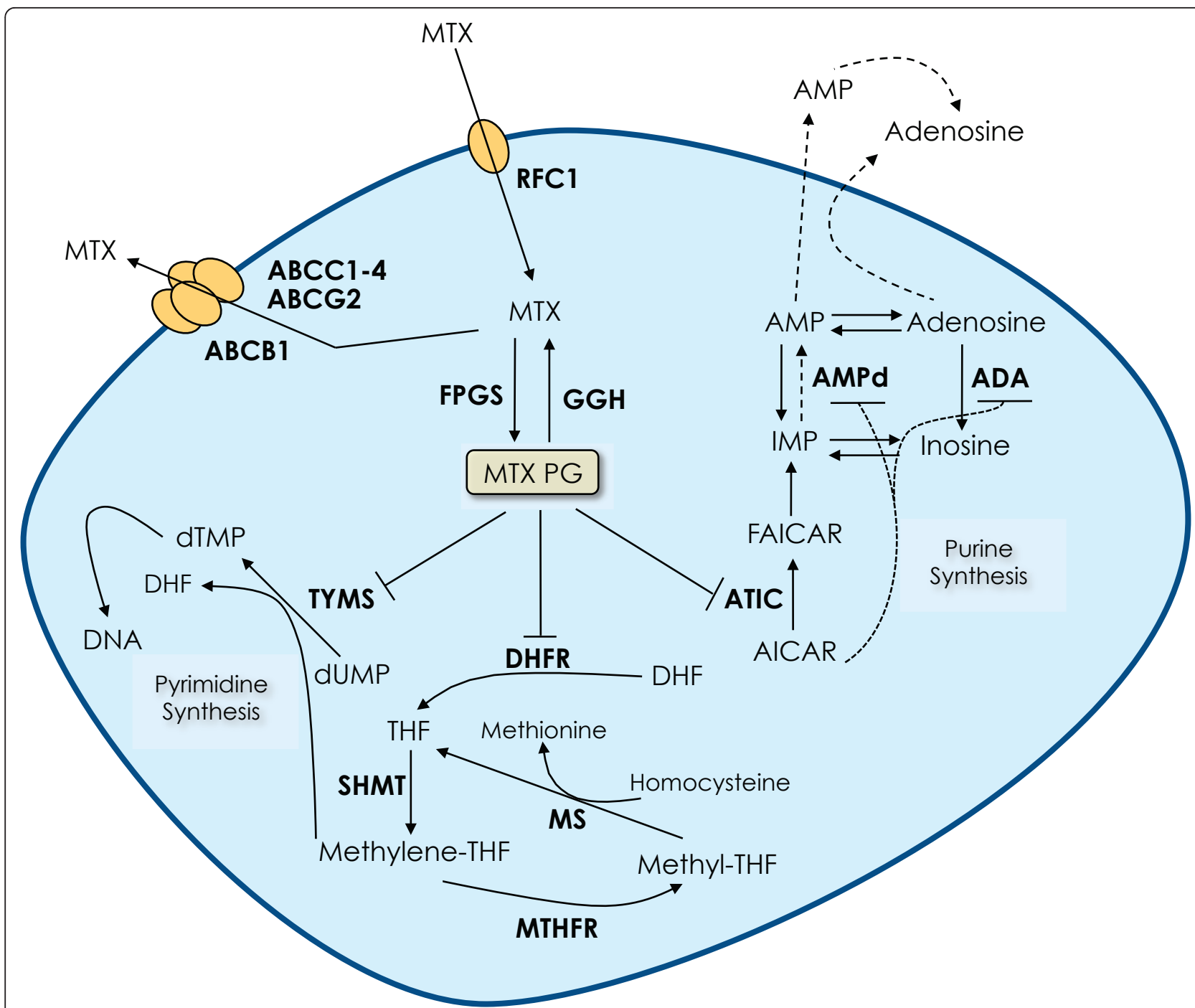

Figure 1 Methotrexate mode of action. Methotrexate (MTX) is actively transported into the cell by the reduced folate carrier 1 (RFC1; also known as SLC19A1) and is then polyglutamated by folylpolyglutamate synthetase (FPGS) to form MTX polyglutamates (MTX PG), which are kept inside the cell [221] and are responsible for MTX anti-inflammatory intracellular actions [17,174]. Glutamates can be removed by $\boldsymbol{\gamma}$-glutamyl hydrolase $(\mathrm{GGH})$ and MTX monoglutamate is rapidly effluxed from the cell via membrane transporters of the ATP-binding cassette (ABC) family [222], especially ABCC1-4 and ABCG2 [223,224]. Inside the cell, MTX PG exert their anti-inflammatory actions through inhibition of essential enzymes of the folate pathway: dihydrofolate reductase (DHFR) [225], blocking the conversion of dihydrofolate (DHF) to tetrahydrofolate (THF) and ultimately leading to depletion of methionine and decreased DNA methylation; thymidylate synthase (TYMS) [226,227], interfering with de novo pyrimidine synthesis; and 5-aminoimidazole-4-carbox-amide ribonucleotide (AICAR) transformylase (ATIC) [148,228], an enzyme of the de novo purine synthesis, causing accumulation of AICAR, which will finally result in increased secretion of adenosine, a strong anti-inflammatory mediator $[229,230]$. The enzyme 5,10-methylene-tetrahydrofolate reductase (MTHFR) is not directly inhibited by MTX, but is affected by it because of its action in the folate pathway [176]. ADA, adenosine deaminase; AMPd, adenosine monophosphate deaminase; dTMP, deoxythymidine monophosphate; dUMP, deoxyuridine monophosphate; FAICAR, 10-formyl 5-aminoimidazole-4-carboxamide ribonucleotide; IMP, inosine monophosphate; Methyl-THF, 5-methyl-tetrahydrofolate; Methylene-THF, 5,10-methylene-tetrahydrofolate; MS, methionine synthase; SHMT, serine hydroxymethil transferase.

5-aminoimidazole-4-carbox-amide ribonucleotide transformylase (ATIC) and, indirectly, 5,10-methylene-tetrahydrofolate reductase (MTHFR) (Figure 1). TYMS is involved in the de novo synthesis of thymidylate, required for cell proliferation. A polymorphic tandem repeat sequence in the promoter region of the TYMS gene has been described, with a variable number of 28 bp repeats $\left(T S E R{ }^{*} \mathrm{R} /{ }^{*} \mathrm{R}\right)$ [186]. Dervieux et al. found TSER 2R/2R patients responded better to MTX than patients with other genotypes, based on physician VAS [187]. Similarly, a Japanese study reported that patients with the TSER 3R/3R genotype required higher MTX 
doses than those carrying at least one allele with two repetitions $(P=0.033)[188]$. Another study also found that the $3 \mathrm{R} / 3 \mathrm{R}$ genotype was associated with worse response to treatment, as part of a pharmacogenetic index comprising SNPs of other genes (RFC1 and ATIC) [149]. However, the same group found that after adjustment for MTX dose and RBC MTX PG levels, 2R/2R patients were less likely to respond, with no association being observed in unadjusted data [150]. Furthermore, James et al. reported better 12-month EULAR responses to MTX in patients carrying one or two 3R alleles treated with MTX, SSZ and HCQ [166]; other authors found no association between MTX response and TSER status $[22,173,189]$. Another polymorphism has been identified which consists of a 6-bp deletion at the 3'UTR region of the TYMS gene [190] and is associated with decreased mRNA stability and expression $[190,191]$. Japanese patients homozygous for this deletion have been shown to have greater reductions in CRP $(P=0.0383)[188]$ and a lower MTX dosage required for a $50 \%$ decrease in CRP $(\beta=-0.268, P=0.039)$ [189] compared to other genotypes, although other studies did not find an association between this polymorphism and MTX response [172,173]. James et al. reported that Australian patients homozygous for the 6-bp deletion were all classified as responders ( 10 versus 0$)$ and a similar non-statistically significant trend was seen for the 6-bp deletion allele as a whole [166]. These authors also found the 3R-del6 haplotype to be clearly associated with a better clinical response to MTX plus SSZ and HCQ (OR $=2.9,95 \%$ CI 1.0 to 9.2) and defended the concept that while currently it is not known which polymorphism of the TYMS gene is better in assessing MTX efficacy, haplotype analysis should be used in future studies analyzing response to treatment [166].

DHFR is a major direct target of MTX PG and, as such, polymorphisms affecting its expression, function, or binding to MTX may interfere with response to treatment [192]. A Japanese study identified a SNP in the 3'UTR of the DHFR gene $(829 \mathrm{C}>\mathrm{T})$, with homozygous 829TT patients having significantly higher expression of the enzyme $(P<0.001)$ [193]. However, the effect of this SNP on response to treatment is unknown and one study of a European population found patients to be $100 \%$ CC wild-type and thus no $829 \mathrm{TT}$ patients were detected [180]. Wessels et al. found no association between SNPs 473G $>$ A or 35289G $>$ A and MTX efficacy [171] as was the case in the study from James et al. on the 19 bp deletion in intron 1 of DHFR gene [166]. A recently published study analyzed the role of SNPs $216 \mathrm{~T}>\mathrm{C}$ and $317 \mathrm{~A}>\mathrm{G}$ and reported no difference in these genotypes between responders and non-responders, using the EULAR response criteria; the authors did find a significant difference, though, when using relative
DAS28 (rDAS28, improvement related to baseline value) as a measure of MTX efficacy, with the 317AA genotype being associated with worse response $(P=0.05)$ [194]. Additional, larger studies are needed to confirm this association.

ATIC is the third enzyme directly inhibited by MTX and it is involved in the de novo purine synthesis and adenosine cycle (Figure 1). The most studied SNP has been the $347 \mathrm{C}>\mathrm{G}$ and, as with other markers, results have been contradictory. Dervieux et al. identified the GG genotype to be associated with lower physician VAS, SJC $[149,187]$ and TJC, as part of a pharmacogenetic index [149]; similar findings were found by Lee et al. using a proxy SNP in linkage disequilibrium with $347 \mathrm{C}>\mathrm{G}(\mathrm{OR}=3.89, P=0.01)$ [195]. However, these were cross-sectional studies analyzing disease activity at a single visit in patients treated with MTX and did not consider baseline scores. This might explain the differences with the findings reported by Wessels et al. in two analyses of the BeSt study population, in which patients with the wild-type homozygous $347 \mathrm{CC}$ allele were more likely to respond to MTX, after adjustment for baseline DAS28 [22,196]. Additionally, several authors found no association between $347 \mathrm{C}>\mathrm{G}$ SNP and response to MTX $[150,166,172,173,197]$. Although differences might be related to different populations, stages of disease and study designs, it is currently unclear which is the true effect of this SNP on the effectiveness of MTX. Other SNPs have recently been identified with different associations to drug response $[173,194]$. Overall, ATIC polymorphisms seem to play a significant role in determining MTX effectiveness, which strengthens the great importance that adenosine is thought to have on the MTX mode of action.

Among all genes potentially influencing MTX efficacy, MTHFR is the best studied. This enzyme is responsible for the conversion of 5,10-methylene-tetrahydrofolate to 5 -methyl-tetrahydrofolate, which is essential to the conversion of homocysteine to methionine [198]. Albeit not a direct target, it is influenced by MTX because of its effects on the intracellular folate pool [176]. Two SNPs have been thoroughly investigated in the last decade, with conflicting results. The $677 \mathrm{C}>\mathrm{T}$ SNP leads to a thermolabile form of MTHFR with reduced activity [199] and among Caucasians around 50\% carry at least one $\mathrm{T}$ allele [200], up to $40 \%$ are CT-heterozygous $(60 \%$ enzyme activity) and approximately $10 \%$ are TT-homozygous (30\% enzyme activity) [176]. The 1298A >C SNP also leads to reduced MTHFR activity, although less severely than the previously mentioned SNP [201], with the variant allele being present in $32 \%$ of the Caucasian population [202]. These polymorphisms seem to interact, as individuals heterozygous for both $677 \mathrm{C}>\mathrm{T}$ and $1298 \mathrm{~A}>\mathrm{C}$ have greater decreases in enzyme activity, 
comparable to those homozygous for the $677 \mathrm{C}>\mathrm{T}$ SNP [203]. Regarding the $677 \mathrm{C}>\mathrm{T}$ SNP, although some authors reported better or worse six-month responses in patients with CC [171,204] or TT [150] genotypes, respectively, and higher rates of remission in carriers of the $\mathrm{T}$ allele [205], a striking number of studies showed no association between $677 \mathrm{C}>\mathrm{T}$ and MTX efficacy $[152,166,188,189,195,206-215]$. In a similar way, data for the 1298A $>$ C SNP is also controversial: while some authors found better responses in 1298AA-positive patients compared to other genotypes [152,171,204], others, on the contrary, reported that $\mathrm{C}$-allele carriers had lower MTX maintenance doses [208,209] and a non-significant tendency for higher remission rates [205]. Most studies failed to identify an association between this SNP and response to MTX [150,166,188,189,210-215]. Moreover, to overcome the discrepancies observed for these polymorphisms two meta-analyses have recently been performed, which included a large number of studies and patients $(\mathrm{n}=$ 2,614 and 1,514, respectively), and in both the authors concluded there was no association between $677 \mathrm{C}>\mathrm{T} /$ $1298 \mathrm{~A}>\mathrm{C}$ and treatment response to MTX $[213,216]$. Thus, currently it is not possible to use MTHFR SNPs as reliable predictors of response to treatment.

Overall, studies evaluating the role of individual SNPs on response to MTX have been inconsistent. This may be related to different study designs, insufficient statistical power and several clinical and pharmacological confounders, such as ethnicity, outcome measures used, folate supplementation, MTX dose, duration and route of administration and concurrent therapies [174]. While large prospective studies are missing, meta-analysis may overcome this problem, but because there are numerous pathways and a considerable number of targets that can be affected by MTX, an individual genetic variant within a single gene is unlikely to result in a significantly altered response, enough to be detected and replicated in different studies. As such, it is probably more advantageous to address more than one gene and polymorphism simultaneously through polygenic analyses, haplotype analyses or gene-gene interactions. Other approaches include interaction of genetic and nongenetic factors and even, as proposed by Stamp et al., genome-wide association studies, which would obviate selection biases and might identify other potential predictors of response not included in current studies [174]. Examples of polygenic analysis include the studies by Dervieux et al., analyzing SNPs of different genes $(A T I C 347 \mathrm{C}>\mathrm{G}$, TSER $2 \mathrm{R} / 3 \mathrm{R}$, RFC1 $80 \mathrm{G}>\mathrm{A}$ ) as part of a pharmacogenetic index, a sum of the homozygous variant genotypes [149,187]. Higher indexes (that is, more variant SNPs) were associated with lower SJC, TJC and disease activity VAS $[149,187]$, as well as with an increased probability of good response, with patients with at least one homozygous variant being 3.7 times more likely to have a good response to MTX than those with none (OR $=3.7, P=0.01)$ [187]. Comparably, Wessels and colleagues investigated polymorphisms in genes involved in the adenosine pathway, such as adenosine monophosphate deaminase (AMPD1) 34C $>\mathrm{T}$, ATIC $347 \mathrm{C}>\mathrm{G}$ and inosine triphosphate pyrophosphatase (ITPA) $94 \mathrm{C}>\mathrm{A}$, and found that patients carrying the AMPD1 $34 \mathrm{~T}$ allele, ATIC $347 \mathrm{CC}$ or ITPA $94 \mathrm{CC}$ had a greater likelihood of having a good response, which was significantly increased if all three favorable genotypes were present (OR $=27.8,95 \%$ CI 3.2 to 250.0) [196]. These SNPs, alongside methylene-tetrahydrofolate dehydrogenase (MTHFD1) 1958G >A, were further included in a clinical pharmacogenetic model that proved to be effective in predicting response to MTX [22]. Haplotype analyses have been conducted in some studies. Urano et al. found the MTHFR $677 \mathrm{C}-1298 \mathrm{C}$ haplotype to be associated with lower MTX dose $(\mathrm{RR}=2.14, P<0.05)$, while no effect was seen in single locus analysis of the $677 \mathrm{C}>\mathrm{T}$ SNP [209]. van der Straaten and colleagues found no association between individual SNPs and MTX efficacy, but identified patients with the GGH 16C-allele and one or no copies of the GGH 452C-16T haplotype as having good clinical improvement at three months, although they concluded that globally the SNPs tested were not likely to be predictive of treatment response [184]. Similarly, as mentioned above, James et al. found the 3R-del6 haplotype of the TYMS gene to significantly correlate with response to treatment [166]. These authors also demonstrated interaction between different SNPs, with patients having the 5-methyltetrahydrofolate-homocysteine methyltransferase (MTR, which codifies for methionine synthase) 2756A allele in combination with either the RFC1 80A allele or the TYMS 3R-del6 haplotype being 35 times more likely to respond to MTX plus SSZ and HCQ $(P<0.0001)$ and 3.4 times more likely to achieve remission $(P=0.04)$ [166]. Hayashi et al. found patients with the RFC1 80AA genotype to respond better if they had no GGH $401 \mathrm{~T}$ alleles, suggesting an interaction between these two SNPs [215]. In the study by Sharma and colleagues a modest interaction, associated with MTX efficacy, was seen between $A B C B 13435 \mathrm{C}>\mathrm{T}$ and GGH 16T>C $(P=0.05)$ [217]. Dervieux et al. recently published two studies addressing this issue and found high-order interactions among SNPs in RFC1, ITPA and ATIC genes, which were associated with efficacy (3.89-fold lower likelihood of response in the absence of favorable combinations, $P<0.001$ ) [218]; on the other study, the authors reported an association among three interacting SNPs (RFC1 80G $>\mathrm{A}, I T P A$ $94 \mathrm{C}>\mathrm{A}$ and $A T I C 347 \mathrm{C}>\mathrm{G})$ and MTX efficacy $(\mathrm{OR}=2.9$, $P<0.01)$, although it was not replicated in a different cohort [219]. While more studies are needed to 
reproduce these findings, as a whole, the analysis of different SNPs in various genes involved in the response to MTX and the interactions between them seems to be a promising approach that may bring more consistency to the body of data on MTX pharmacogenetics.

\section{Discussion}

We found a high discrepancy between studies' results, making it difficult to obtain clear-cut predictors of response to MTX and other synthetic DMARDs (Tables 2, 3 and 4). This might be related to the heterogeneity in study types, population size and ethnicity, disease characteristics and outcome measures applied. While some factors (female gender, established disease, previous DMARD use, smoking, high disease activity determined by composite scores, absence of concomitant corticosteroids, SEpositivity) seem to be individually associated with a weaker response to MTX, drug effectiveness is ultimately the result of multiple clinical and biological (genetic and nongenetic) variables that interact to determine whether a patient responds or not to a particular drug. This explains why in most studies baseline factors merely associate weakly with better or worse response but individually fail to distinguish responders and nonresponders [15].

In line with this hypothesis, recent studies addressing different types of factors and the interaction between them have been shown to constitute a very promising approach to define, at drug start, which patients will respond and which will not $[22,173]$. In the study by Wessels et al., the authors applied a clinical pharmacogenetic score including clinical, genetic and nongenetic variables found to be associated with treatment response (gender, RF, DAS, smoking status, AMPD1 34C > T, ITPA 94C>A, ATIC 347C>G and MTHFD1 1958G>A) and correctly classified around 54\% of the patients as responders or nonresponders (42\% for responders and 63\% for nonresponders); furthermore, scores of $\leq 3.5$ had a positive predictive value of $95 \%$ and scores $\geq 6$ had a negative predictive value of $86 \%$ [22]. When the genetic variables were removed from the model, the set of clinical and biological nongenetic factors correctly predicted response in only $29 \%$ of the cases (36\% for responders and $23 \%$ for nonresponders), although positive and negative predictive values were still very high $(89 \%$ and $92 \%$, respectively) [22]. These findings clearly reinforce the notion that considering groups of potential predictive factors will be more efficient than simply analyzing them individually. Thus, including clinical, genetic and nongenetic biological factors is more effective than a parallel approach. Yet, this model has not been applied routinely in other populations or studies and to date few authors have replicated this type of approach, with most studies still focusing on searching for associations between individual markers and treatment outcome.
In this review, we were able to identify factors that seem to be associated with response to treatment, especially regarding clinical markers where the amount of evidence is greater (Table 2). Female gender, smoking, established disease, previous DMARD use, high disease activity measured by composite scores and the absence of concomitant corticosteroids are associated with a lower response to MTX. This is consistent with the results of the meta-analysis by Drouin et al. [15], with the difference that smoking was considered together with RF-positivity for early RA only and that corticosteroids were not shown to be predictive of clinical response to MTX.

A few comments should be made on these results. First, analyzing a significant number of studies for each factor may help overcome heterogeneity by giving a global view of the data and determining the direction evidence is pointing at; second, caution is required when interpreting results of individual negative studies; third, several studies consider MTX in association with other DMARDs, making it difficult to ascertain whether the observed effect in those cases is the result of MTX itself, the associated DMARD or the combination of both; and finally, given the paucity of studies specifically analyzing other DMARDs, it seems inappropriate to extend these conclusions to drugs other than MTX.

Biological markers, both genetic and nongenetic, have also been extensively studied. Despite some exceptions, most of the results lack confirmation and replication in larger studies (Table 3 and Table 4). The exceptions are RF, ACPA and SE, all thoroughly analyzed, given their role as predictors of poor prognosis. While most evidence points towards an absence of effect of RF on DMARD effectiveness (except for some early RA studies), SE-positivity (and especially the $H L A-D R B 1 * 04$ allele) seems to be associated with a worse response to MTX (non-extendable to persistent remission). The presence of ACPA has a less well-defined effect, with solid data suggesting it does not influence response to DMARDs in early RA, although it may play a role in UA patients' response to MTX. Other nongenetic biomarkers have been identified in smaller studies and some may deserve further clarification as potential predictive markers through larger studies.

Pharmacogenetics remains a promising field but to date, and regardless of intense research, no SNPs have been clearly identified as predictors of response to MTX [17]. This is probably related to the influence of several genes and polymorphisms on the determination of the final drug effectiveness; recent studies continue to identify new SNPs in crucial pathways, underlining the complexity of this area. Valid approaches to overcome this issue include analysis of haplotypes, multiple-gene models, and interactions of different genes with nongenetic factors.

As previously mentioned, combining different factors might be useful in determining whether a patient will 
respond to MTX. Although models such as the one developed by Wessels et al. [22] might be more reliable for achieving this purpose, we can assume that starting and maintaining treatment with MTX will probably be more effective in male, non-smoking, DMARD-naïve, SE-negative patients with early, mild disease and that corticosteroids should be added as adjuvants. Other variables, such as genetic determinants, will be valuable in increasing the accuracy of the prediction model, but at the moment it is not possible to define them with certainty.

Standardization of studies addressing predictors of response is needed. On the one hand, the inconsistencies in results may reflect differences in study-design, population size and features (ethnicity, age, socioeconomic context), disease characteristics (early/established, activity, disability), pharmacological variables (dose, previous or concomitant DMARD, corticosteroids, NSAIDs) and, most importantly, outcome definitions used. On the other hand, this heterogeneity makes it harder to compare studies and, generally, systematic literature reviews and meta-analysis are forced to exclude a great number of studies, with few being left to analyze. In this review we included a wide variety of studies and while this is certainly a limitation it also allowed us to gather more data and have a broader picture of current evidence. Of major importance is definition of response, a question already raised by other authors $[15,16,220]$. Response to treatment may be defined as adequate symptom and activity control and this can be assessed by isolated clinical variables (VAS, SJC, TJC, pain VAS) or composite scores (SDAI, CDAI, EULAR response), but it must be taken into account that this is not the same as disease progression slowdown or halt. However, given the direct relationship between higher disease activity and progression, assessing response to treatment as improvement in activity or symptoms seems an adequate approach to use in studies. In this sense, we think the best way to evaluate response is through changes in composite scores such as DAS, DAS28, SDAI and CDAI and especially using EULAR response criteria, because these are the only measurements to encompass both change in time and endpoint values, assuring that patients with good response have a significant decrease in disease activity and also have reached low disease activity. By using these standard measures of response to treatment, comparison between studies would be facilitated and prediction capacities would be easier to detect.

\section{Conclusions}

In summary, predicting response to MTX and other DMARDs is a stimulating challenge in RA research, not yet fully accomplished. Although it is still not possible to determine whether or not a patient will respond to MTX, we identified clinical and biological factors associated with increased effectiveness: male gender, non- smoking, early disease stage, absence of previous DMARD use, lower baseline disease activity measured by composite scores, concomitant corticosteroids and SE-negativity. Combining distinct factors, adopting new approaches in emerging fields and applying them in larger standardized studies will help define prediction models and reach the longed-for goal of tailor-made therapy.

\section{Abbreviations}

3'-UTR: 3'-untranslated region; 7-OH-MTX: 7-hydroxy-methotrexate; ABC: ATPbinding cassette; ACPA: anti-citrullinated protein antibodies; ACR: American College of Rheumatology; ADA: adenosine deaminase; AICAR: 5aminoimidazole-4-carbox-amide ribonucleotide; ALT: alanine aminotransferase; AMPd: adenosine monophosphate deaminase; anti-CCP2: second-generation anti-cyclic citrullinated peptide; anti-MCV: anti-modified citrullinated vimentin antibodies; AST: aspartate aminotransferase; ATIC: 5aminoimidazole-4-carbox-amide ribonucleotide transformylase; bp: base pair; CBC: complete blood count; CDAl: clinical disease activity index; $\mathrm{Cl}$ : confidence interval; CRP: C reactive protein; DAS: disease activity score; DAS28: disease activity score - 28 joint; DHF: dihydrofolate; DHFR: dihydrofolate reductase; DMARDs: disease-modifying antirheumatic drugs; dTMP: deoxythymidine monophosphate; dUMP: deoxyuridine monophosphate; ESR: erythrocyte sedimentation rate; EULAR: European League Against Rheumatism; FAICAR: 10-formyl 5-aminoimidazole-4carboxamide ribonucleotide; FPGS: folylpolyglutamate synthetase; GGH: $\boldsymbol{\gamma}$ glutamyl hydrolase; HAQ: health assessment questionnaire; Hb: hemoglobin; HCQ: hydroxychloroquine; HLA: human leukocyte antigen; HR: hazard ratio; IFN: interferon; IgG: immunoglobulin G; IL: interleukin; IL-1ra: interleukin-1 receptor antagonist; IMP: inosine monophosphate; ITPA: inosine triphosphate pyrophosphatase; Methyl-THF: 5-methyl-tetrahydrofolate; Methylene-THF: 5:10-methylene-tetrahydrofolate; MMP-3: matrix metalloproteinase-3; MS: methionine synthase; MTHFD1: methylene-tetrahydrofolate dehydrogenase; MTHFR: 5:10-methylene-tetrahydrofolate reductase; MTR: 5-

methyltetrahydrofolate-homocysteine methyltransferase; MTX: methotrexate; MTX PG: methotrexate polyglutamates; NSAIDs: non-steroidal antiinflammatory drugs; OR: odds ratio; PBMC: peripheral blood mononuclear cells; RA: rheumatoid arthritis; RBC: red blood cells; RCT: randomized clinical trial; rDAS28: relative disease activity score - 28 joint; RF: rheumatoid factor; RFC1: reduced folate carrier 1; SCD30: soluble CD30; SD: standard deviation; SDAl: simplified disease activity index; SE: shared epitope; SHMT: serine hydroxymethil transferase; sIL-2R: soluble interleukin-2 receptor; SJC: swollen joint count; SNPs: single nucleotide polymorphisms; SR: systematic review; SSZ: sulphasalazine; sTNFR: soluble tumor necrosis factor receptor; THF: tetrahydrofolate; TJC: tender joint count; TNF: tumor necrosis factor; TNFID ${ }_{50}$ : dose required to suppress by $50 \%$ the production of tumor necrosis factor; TSER: thymidylate synthase enhancer region; TYMS: thymidylate synthase; UA: undifferentiated arthritis; ULN: upper limit of normal; VAS: visual analogue scale.

\section{Authors' contributions}

All authors participated in the protocol design. VCR performed the literature search, drafted and edited the manuscript, including figures and tables. HC and JEF reviewed, commented and complemented the manuscript. All authors have read and approved the final manuscript.

\section{Authors' information}

VCR, MD is a research trainee at the Rheumatology Research Unit, Instituto de Medicina Molecular, Faculdade de Medicina da Universidade de Lisboa, Lisbon, Portugal. He is also a Rheumatology fellow at the Lisbon Academic Medical Centre, Portugal.

$\mathrm{HC}, \mathrm{MD}, \mathrm{MMSc}, \mathrm{PhD}$ is Principal Investigator at the Rheumatology Research Unit, Instituto de Medicina Molecular, Faculdade de Medicina da Universidade de Lisboa. She is Assistant Professor of Rheumatology and a Rheumatology Consultant at the Lisbon Academic Medical Centre. She is also the National Coordinator of Reuma.pt (Rheumatic Diseases Portuguese Register, Portuguese Society of Rheumatology). 
JEF, MD, PhD is the Head of the Rheumatology Research Unit and of the Biobank at Instituto de Medicina Molecular, Faculdade de Medicina da Universidade de Lisboa. He is Assistant Professor of Rheumatology and a Rheumatology Consultant at the Lisbon Academic Medical Centre. He is also the President-Elect of the Portuguese Society of Rheumatology.

\section{Competing interests}

The authors declare that they have no competing interests.

\section{Author details}

${ }^{1}$ Rheumatology Research Unit, Instituto de Medicina Molecular - Faculdade de Medicina da Universidade de Lisboa, Edifício Egas Moniz - Av. Prof. Egas Moniz, Lisboa 1649-028, Portugal. Rheumatology Department, Lisbon Academic Medical Centre, Av. Prof. Egas Moniz, Lisboa 1649-028, Portugal.

Received: 5 September 2012 Accepted: 23 January 2013

Published: 23 January 2013

\section{References}

1. Aletaha D, Smolen JS: The rheumatoid arthritis patient in the clinic: comparing more than 1,300 consecutive DMARD courses. Rheumatology (Oxford) 2002, 41:1367-1374.

2. Sokka T, Pincus T: Contemporary disease modifying antirheumatic drugs (DMARD) in patients with recent onset rheumatoid arthritis in a US private practice: methotrexate as the anchor drug in $90 \%$ and new DMARD in 30\% of patients. J Rheumatol 2002, 29:2521-2524

3. Kinder AJ, Hassell AB, Brand J, Brownfield A, Grove M, Shadforth MF: The treatment of inflammatory arthritis with methotrexate in clinical practice: treatment duration and incidence of adverse drug reactions. Rheumatology (Oxford) 2005, 44:61-66.

4. Aletaha D, Smolen JS: Effectiveness profiles and dose dependent retention of traditional disease modifying antirheumatic drugs for rheumatoid arthritis. An observational study. J Rheumatol 2002, 29:1631-1638.

5. Maetzel A, Wong A, Strand V, Tugwell P, Wells G, Bombardier C: Metaanalysis of treatment termination rates among rheumatoid arthritis patients receiving disease-modifying anti-rheumatic drugs. Rheumatology (Oxford) 2000, 39:975-981.

6. Fonseca JE, Viana Queiroz M: Estudo da eficácia, tolerância e aceitabilidade da terapêutica da artrite reumatóide com metotrexato experiência dos últimos 10 anos. Boletim CIAR 1997, , VII: 83-88.

7. Kremer JM, Genovese MC, Cannon GW, Caldwell JR, Cush JJ, Furst DE, Luggen ME, Keystone E, Weisman MH, Bensen WM, Kaine JL, Ruderman EM, Coleman P, Curtis DL, Kopp EJ, Kantor SM, Waltuck J, Lindsley HB, Markenson JA, Strand V, Crawford B, Fernando I, Simpson K, Bathon JM: Concomitant leflunomide therapy in patients with active rheumatoid arthritis despite stable doses of methotrexate. A randomized, doubleblind, placebo-controlled trial. Ann Intern Med 2002, 137:726-733.

8. Mourao AF, Fonseca JE, Canhao H, Santos MJ, Bernardo A, Cordeiro A, Cravo AR, Ribeiro A, Teixeira A, Barcelos A, Malcata A, Faustino A, Duarte C, Ribeiro C, Nour D, Araujo D, Sousa E, Mariz E, Ramos F, Vinagre F, Ventura FS, Sequeira G, Santos H, Branco JC, Gomes JA, Silva JA, Ramos J, Santo JE, Costa JA, Silva JA, et al: [Practical guide for the use of biological agents in rheumatoid arthritis - December 2011 update]. Acta Reumatol Port 2011, 36:389-395.

9. Mourao AF, Canhao H, Moura RA, Cascao R, Weinmann P, Rodrigues A, Polido-Pereira J, Resende C, Capela S, Silva JA, Fonseca JE: Markers of progression to rheumatoid arthritis: discriminative value of the new ACR/EULAR rheumatoid arthritis criteria in a Portuguese population with early polyarthritis. Acta Reumatol Port 2011, 36:370-376.

10. Visser K, Katchamart W, Loza E, Martinez-Lopez JA, Salliot C, Trudeau J, Bombardier C, Carmona L, van der Heijde D, Bijlsma JW, Boumpas DT, Canhao H, Edwards CJ, Hamuryudan V, Kvien TK, Leeb BF, Martin-Mola EM, Mielants H, Muller-Ladner U, Murphy G, Ostergaard M, Pereira IA, RamosRemus C, Valentini G, Zochling J, Dougados M: Multinational evidencebased recommendations for the use of methotrexate in rheumatic disorders with a focus on rheumatoid arthritis: integrating systematic literature research and expert opinion of a broad international panel of rheumatologists in the 3E Initiative. Ann Rheum Dis 2009, 68:1086-1093.

11. Weinblatt ME, Kaplan H, Germain BF, Block S, Solomon SD, Merriman RC, Wolfe F, Wall B, Anderson L, Gall E, Torretti D, Weissman B: Methotrexate in rheumatoid arthritis. A five-year prospective multicenter study. Arthritis Rheum 1994, 37:1492-1498.

12. O'Dell JR: Therapeutic strategies for rheumatoid arthritis. N Engl J Med 2004, 350:2591-2602.

13. Machold KP, Stamm TA, Nell VP, Pflugbeil S, Aletaha D, Steiner G, Uffmann M, Smolen JS: Very recent onset rheumatoid arthritis: clinical and serological patient characteristics associated with radiographic progression over the first years of disease. Rheumatology (Oxford) 2007, 46:342-349.

14. Hider SL, Silman AJ, Thomson W, Lunt M, Bunn D, Symmons DP: Can clinical factors at presentation be used to predict outcome of treatment with methotrexate in patients with early inflammatory polyarthritis? Ann Rheum Dis 2009, 68:57-62.

15. Drouin J, Haraoui B: Predictors of clinical response and radiographic progression in patients with rheumatoid arthritis treated with methotrexate monotherapy. J Rheumatol 2010, 37:1405-1410.

16. Hider SL, Buckley C, Silman AJ, Symmons DP, Bruce IN: Factors influencing response to disease modifying antirheumatic drugs in patients with rheumatoid arthritis. J Rheumatol 2005, 32:11-16.

17. Ranganathan $P$ : The challenges of methotrexate pharmacogenetics in rheumatoid arthritis. Pharmacogenomics 2012, 13:377.

18. Bansard C, Lequerre T, Daveau M, Boyer O, Tron F, Salier JP, Vittecoq O, LeLoet $X$ : Can rheumatoid arthritis responsiveness to methotrexate and biologics be predicted? Rheumatology (Oxford) 2009, 48:1021-1028.

19. Scherer HU, Dorner T, Burmester GR: Patient-tailored therapy in rheumatoid arthritis: an editorial review. Curr Opin Rheumatol 2010, 22:237-245.

20. Polido-Pereira J, Vieira-Sousa E, Fonseca JE: Rheumatoid arthritis: what is refractory disease and how to manage it? Autoimmun Rev 2011, 10:707-713.

21. Guidelines for the management of rheumatoid arthritis: 2002 Update. Arthritis Rheum 2002, 46:328-346.

22. Wessels JA, van der Kooij SM, le Cessie S, Kievit W, Barerra P, Allaart CF, Huizinga TW, Guchelaar HJ: A clinical pharmacogenetic model to predict the efficacy of methotrexate monotherapy in recent-onset rheumatoid arthritis. Arthritis Rheum 2007, 56:1765-1775.

23. Hoekstra M, van Ede AE, Haagsma CJ, van de Laar MA, Huizinga TW, Kruijsen MW, Laan RF: Factors associated with toxicity, final dose, and efficacy of methotrexate in patients with rheumatoid arthritis. Ann Rheum Dis 2003, 62:423-426.

24. Anderson JJ, Wells G, Verhoeven AC, Felson DT: Factors predicting response to treatment in rheumatoid arthritis: the importance of disease duration. Arthritis Rheum 2000, 43:22-29.

25. Saevarsdottir S, Wallin H, Seddighzadeh M, Ernestam S, Geborek P, Petersson IF, Bratt J, van Vollenhoven RF: Predictors of response to methotrexate in early DMARD naive rheumatoid arthritis: results from the initial open-label phase of the SWEFOT trial. Ann Rheum Dis 2011, 70:469-475.

26. Stranzl T, Wolf J, Leeb BF, Smolen JS, Pirker R, Filipits M: Expression of folylpolyglutamyl synthetase predicts poor response to methotrexate therapy in patients with rheumatoid arthritis. Clin Exp Rheumatol 2003 21:27-32.

27. Vazquez I, Graell E, Gratacos J, Canete JD, Vinas O, Ercilla MG, Gomez A, Hernandez MV, Rodriguez-Cros JR, Larrosa M, Sanmarti R: Prognostic markers of clinical remission in early rheumatoid arthritis after two years of DMARDs in a clinical setting. Clin Exp Rheumatol 2007, 25:231-238.

28. Maillefert JF, Puechal X, Falgarone G, Lizard G, Ornetti P, Solau E, Legre V, Liote F, Sibilia J, Morel J, Maynadie M: Prediction of response to disease modifying antirheumatic drugs in rheumatoid arthritis. Joint Bone Spine 2010, 77:558-563.

29. Ma MH, Ibrahim F, Walker D, Hassell A, Choy EH, Kiely PD, Williams R, Walsh DA, Young A, Scott DL: Remission in early rheumatoid arthritis: predicting treatment response. J Rheumatol 2012, 39:470-475.

30. Choy EH, Smith CM, Farewell V, Walker D, Hassell A, Chau L, Scott DL: Factorial randomised controlled trial of glucocorticoids and combination disease modifying drugs in early rheumatoid arthritis. Ann Rheum Dis 2008, 67:656-663.

31. Kiely P, Williams R, Walsh D, Young A: Contemporary patterns of care and disease activity outcome in early rheumatoid arthritis: the ERAN cohort. Rheumatology (Oxford) 2009, 48:57-60. 
32. Capell HA, Porter DR, Madhok R, Hunter JA: Second line (disease modifying) treatment in rheumatoid arthritis: which drug for which patient? Ann Rheum Dis 1993, 52:423-428.

33. Situnayake RD, McConkey B: Clinical and laboratory effects of prolonged therapy with sulfasalazine, gold or penicillamine: the effects of disease duration on treatment response. J Rheumatol 1990, 17:1268-1273.

34. Matteson EL, Weyand CM, Fulbright JW, Christianson TJ, McClelland RL, Goronzy JJ: How aggressive should initial therapy for rheumatoid arthritis be? Factors associated with response to 'non-aggressive' DMARD treatment and perspective from a 2-yr open label trial. Rheumatology (Oxford) 2004, 43:619-625.

35. van den Borne BE, Landewe RB, Rietveld JH, Goei The HS, Griep EN, Breedveld FC, Dijkmans BA: Chloroquine therapy in patients with recentonset rheumatoid arthritis: the clinical response can be predicted by the low level of acute-phase reaction at baseline. Clin Rheumatol 1999, 18:369-372.

36. van Roon EN, Hoekstra M, Tobi H, Jansen $T L$, Bernelot Moens HJ, Brouwers JR, van de Laar MA: Leflunomide in the treatment of rheumatoid arthritis. An analysis of predictors for treatment continuation. Br J Clin Pharmacol 2005, 60:319-325.

37. Mottonen $T$, Hannonen $P$, Korpela M, Nissila M, Kautiainen $H$, llonen J, Laasonen L, Kaipiainen-Seppanen O, Franzen P, Helve T, Koski J, Gripenberg-Gahmberg M, Myllykangas-Luosujarvi R, Leirisalo-Repo M: Delay to institution of therapy and induction of remission using single-drug or combination-disease-modifying antirheumatic drug therapy in early rheumatoid arthritis. Arthritis Rheum 2002, 46:894-898.

38. Scott DL: The diagnosis and prognosis of early arthritis: rationale for new prognostic criteria. Arthritis Rheum 2002, 46:286-290.

39. The effect of age and renal function on the efficacy and toxicity of methotrexate in rheumatoid arthritis. Rheumatoid Arthritis Clinical Trial Archive Group. J Rheumatol 1995, 22:218-223.

40. Bologna C, Viu P, Jorgensen C, Sany J: Effect of age on the efficacy and tolerance of methotrexate in rheumatoid arthritis. Br J Rheumatol 1996, 35:453-457.

41. Wolfe F, Cathey MA: The effect of age on methotrexate efficacy and toxicity. J Rheumatol 1991, 18:973-977.

42. Combe B, Cantagrel A, Goupille P, Bozonnat MC, Sibilia J, Eliaou JF, Meyer O, Sany J, Dubois A, Daures JP, Dougados M: Predictive factors of 5year health assessment questionnaire disability in early rheumatoid arthritis. J Rheumatol 2003, 30:2344-2349.

43. Helliwell PS, Ibrahim G: Ethnic differences in responses to disease modifying drugs. Rheumatology (Oxford) 2003, 42:1197-1201.

44. Criswell LA, Lum RF, Turner KN, Woehl B, Zhu Y, Wang J, Tiwari HK, Edberg JC, Kimberly RP, Moreland LW, Seldin MF, Bridges SL: The influence of genetic variation in the HLA-DRB1 and LTA-TNF regions on the response to treatment of early rheumatoid arthritis with methotrexate or etanercept. Arthritis Rheum 2004, 50:2750-2756.

45. Hodkinson B, Musenge E, Ally M, Meyer PW, Anderson R, Tikly M: Response to traditional disease-modifying anti-rheumatic drugs in indigent South Africans with early rheumatoid arthritis. Clin Rheumatol 2011, 31:613-619.

46. Papadopoulos NG, Alamanos Y, Voulgari PV, Epagelis EK, Tsifetaki N, Drosos AA: Does cigarette smoking influence disease expression, activity and severity in early rheumatoid arthritis patients? Clin Exp Rheumatol 2005, 23:861-866.

47. Manfredsdottir VF, Vikingsdottir T, Jonsson T, Geirsson AJ, Kjartansson O, Heimisdottir M, Sigurdardottir SL, Valdimarsson H, Vikingsson A: The effects of tobacco smoking and rheumatoid factor seropositivity on disease activity and joint damage in early rheumatoid arthritis. Rheumatology (Oxford) 2006, 45:734-740.

48. Saag KG, Cerhan JR, Kolluri S, Ohashi K, Hunninghake GW, Schwartz DA: Cigarette smoking and rheumatoid arthritis severity. Ann Rheum Dis 1997, 56:463-469.

49. Wolfe F: The effect of smoking on clinical, laboratory, and radiographic status in rheumatoid arthritis. J Rheumatol 2000, 27:630-637.

50. Saevarsdottir S, Wedren S, Seddighzadeh M, Bengtsson C, Wesley A, Lindblad S, Askling J, Alfredsson L, Klareskog L: Patients with early rheumatoid arthritis who smoke are less likely to respond to treatment with methotrexate and tumor necrosis factor inhibitors: observations from the Epidemiological Investigation of Rheumatoid Arthritis and the Swedish Rheumatology Register cohorts. Arthritis Rheum 2011, 63:26-36.
51. Westhoff G, Rau R, Zink A: Rheumatoid arthritis patients who smoke have a higher need for DMARDs and feel worse, but they do not have more joint damage than non-smokers of the same serological group. Rheumatology (Oxford) 2008, 47:849-854.

52. Stamp LK, O'Donnell JL, Chapman PT, Zhang M, Frampton C, James J, Barclay ML: Determinants of red blood cell methotrexate polyglutamate concentrations in rheumatoid arthritis patients receiving long-term methotrexate treatment. Arthritis Rheum 2009, 60:2248-2256.

53. Maradit-Kremers H, Nicola PJ, Crowson CS, O'Fallon WM, Gabriel SE: Patient, disease, and therapy-related factors that influence discontinuation of disease-modifying antirheumatic drugs: a population-based incidence cohort of patients with rheumatoid arthritis. J Rheumatol 2006, 33:248-255.

54. Fonseca JE, Canhao H, Teixeira da CJ, Pereira da SJ, Queiroz MV: Global functional status in rheumatoid arthritis: disease duration and patient age. Clin Rheumatol 2002, 21:32-34.

55. O'Dell JR, Nepom BS, Haire C, Gersuk VH, Gaur L, Moore GF, Drymalski W, Palmer W, Eckhoff PJ, Klassen LW, Wees S, Thiele G, Nepom GT: HLA-DRB1 typing in rheumatoid arthritis: predicting response to specific treatments. Ann Rheum Dis 1998, 57:209-213.

56. Wolfe F, Hawley DJ, Cathey MA: Termination of slow acting antirheumatic therapy in rheumatoid arthritis: a 14-year prospective evaluation of 1017 consecutive starts. J Rheumatol 1990, 17:994-1002.

57. O'Dell JR, Haire CE, Erikson N, Drymalski W, Palmer W, Eckhoff PJ, Garwood V, Maloley P, Klassen LW, Wees S, Klein H, Moore GF: Treatment of rheumatoid arthritis with methotrexate alone, sulfasalazine and hydroxychloroquine, or a combination of all three medications. N Engl J Med 1996, 334:1287-1291.

58. Egsmose C, Lund B, Borg G, Pettersson H, Berg E, Brodin U, Trang L: Patients with rheumatoid arthritis benefit from early 2 nd line therapy: 5 year followup of a prospective double blind placebo controlled study. J Rheumatol 1995, 22:2208-2213.

59. Munro R, Hampson R, McEntegart A, Thomson EA, Madhok R, Capell H: Improved functional outcome in patients with early rheumatoid arthritis treated with intramuscular gold: results of a five year prospective study. Ann Rheum Dis 1998, 57:88-93.

60. van der Heide A, Jacobs JW, Bijlsma JW, Heurkens AH, van BoomaFrankfort C, van der Veen MJ, Haanen HC, Hofman DM, van AlbadaKuipers GA, ter Borg EJ, Brus HL, Dinant HJ, Kruize AA, Schenk Y: The effectiveness of early treatment with "second-line" antirheumatic drugs. A randomized, controlled trial. Ann Intern Med 1996, 124:699-707.

61. Tsakonas E, Fitzgerald AA, Fitzcharles MA, Cividino A, Thorne JC, M'Seffar A, Joseph L, Bombardier C, Esdaile JM: Consequences of delayed therapy with second-line agents in rheumatoid arthritis: a 3 year followup on the hydroxychloroquine in early rheumatoid arthritis (HERA) study. $J$ Rheumatol 2000, 27:623-629.

62. Cush JJ: Early rheumatoid arthritis - is there a window of opportunity? J Rheumatol Suppl 2007, 80:1-7.

63. Emery P: Early rheumatoid arthritis: therapeutic strategies. Scand J Rheumatol Suppl 1994, 100:3-7.

64. Emery P: Evidence supporting the benefit of early intervention in rheumatoid arthritis. J Rheumatol Supp/ 2002, 66:3-8.

65. Wijnands MJ, van't Hof MA, van Leeuwen MA, van Rijswijk MH, van de Putte LB, van Riel PL: Long-term second-line treatment: a prospective drug survival study. Br J Rheumatol 1992, 31:253-258.

66. Lie E, Heiberg M, Nordvag B, Rodevand E, Kaufmann C, Mikkelsen K, Kvien TK: Predictors of response to methotrexate treatment: results from a longitudinal observational study of 876 patients with RA. Ann Rheum Dis 2006, 65(Suppl II):342.

67. Fries JF, Williams CA, Singh G, Ramey DR: Response to therapy in rheumatoid arthritis is influenced by immediately prior therapy. $J$ Rheumatol 1997, 24:838-844.

68. Aletaha D, Funovits J, Keystone EC, Smolen JS: Disease activity early in the course of treatment predicts response to therapy after one year in rheumatoid arthritis patients. Arthritis Rheum 2007, 56:3226-3235.

69. Svensson B, Schaufelberger C, Teleman A, Theander J: Remission and response to early treatment of RA assessed by the Disease Activity Score. BARFOT study group. Better Anti-rheumatic Farmacotherapy. Rheumatology (Oxford) 2000, 39:1031-1036.

70. Gossec L, Dougados M, Goupille P, Cantagrel A, Sibilia J, Meyer O, Sany J, Daures JP, Combe B: Prognostic factors for remission in early rheumatoid 
arthritis: a multiparameter prospective study. Ann Rheum Dis 2004, 63:675-680.

71. Kavanaugh A, Klareskog L, van der Heijde D, Li J, Freundlich B, Hooper M: Improvements in clinical response between 12 and 24 weeks in patients with rheumatoid arthritis on etanercept therapy with or without methotrexate. Ann Rheum Dis 2008, 67:1444-1447.

72. Thompson PW, Silman AJ, Kirwan JR, Currey HL: Articular indices of joint inflammation in rheumatoid arthritis. Correlation with the acute-phase response. Arthritis Rheum 1987, 30:618-623.

73. Verstappen SM, van Albada-Kuipers GA, Bijlsma JW, Blaauw AA, Schenk Y, Haanen HC, Jacobs JW: A good response to early DMARD treatment of patients with rheumatoid arthritis in the first year predicts remission during follow up. Ann Rheum Dis 2005, 64:38-43.

74. Mottonen $T$, Hannonen $P$, Leirisalo-Repo M, Nissila M, Kautiainen $H_{\text {, }}$ Korpela $M$, Laasonen $L$, Julkunen $H$, Luukkainen $R$, Vuori $K$, Paimela $L$, Blafield H, Hakala M, Ilva K, Yli-Kerttula U, Puolakka K, Jarvinen P, Hakola M, Piirainen H, Ahonen J, Palvimaki I, Forsberg S, Koota K, Friman C: Comparison of combination therapy with single-drug therapy in early rheumatoid arthritis: a randomised trial. FIN-RACo trial group. Lancet 1999, 353:1568-1573.

75. Goetz I, Carter GC, Lucero M, Zarotsky V, Alatorre Cl, Cantrell RA, Paczkowski R, Sterling KL: Review of treatment response in rheumatoid arthritis: assessment of heterogeneity. Curr Med Res Opin 2011, 27:697-711.

76. Boers M, Verhoeven AC, Markusse HM, van de Laar MA, Westhovens R, van Denderen JC, van Zeben D, Dijkmans BA, Peeters AJ, Jacobs P, van den Brink HR, Schouten HJ, van der Heijde DM, Boonen A, van der Linden S: Randomised comparison of combined step-down prednisolone, methotrexate and sulphasalazine with sulphasalazine alone in early rheumatoid arthritis. Lancet 1997, 350:309-318.

77. Bakker MF, Jacobs JW, Welsing PM, Verstappen SM, Tekstra J, Ton E, Geurts MA, van der Werf JH, van Albada-Kuipers GA, Jahangier-de Veen ZN, van der Veen MJ, Verhoef CM, Lafeber FP, Bijlsma JW: Low-dose prednisone inclusion in a methotrexate-based, tight control strategy for early rheumatoid arthritis: a randomized trial. Ann Intern Med 2012, 156:329-339.

78. Svensson B, Boonen A, Albertsson K, van der Heijde D, Keller C, Hafstrom I: Low-dose prednisolone in addition to the initial disease-modifying antirheumatic drug in patients with early active rheumatoid arthritis reduces joint destruction and increases the remission rate: a two-year randomized trial. Arthritis Rheum 2005, 52:3360-3370.

79. Hafstrom I, Albertsson K, Boonen A, van der Heijde D, Landewe R, Svensson B: Remission achieved after 2 years treatment with low-dose prednisolone in addition to disease-modifying anti-rheumatic drugs in early rheumatoid arthritis is associated with reduced joint destruction still present after 4 years: an open 2-year continuation study. Ann Rheum Dis 2009, 68:508-513.

80. Aletaha D, Neogi T, Silman AJ, Funovits J, Felson DT, Bingham CO 3rd, Birnbaum NS, Burmester GR, Bykerk VP, Cohen MD, Cohen MD, Combe B, Costenbader KH, Dougados M, Emery P, Ferraccioli G, Hazes JM, Hobbs K, Huizinga TW, Kavanaugh A, Kay J, Kvien TK, Laing T, Mease P, Menard HA, Moreland LW, Naden RL, Pincus T, Smolen JS, Stanislawska-Biernat E, Symmons D, et al: 2010 rheumatoid arthritis classification criteria: an American College of Rheumatology/European League Against Rheumatism collaborative initiative. Ann Rheum Dis 2010, 69:1580-1588.

81. Mottonen T, Paimela L, Leirisalo-Repo M, Kautiainen H, Ilonen J, Hannonen P: Only high disease activity and positive rheumatoid factor indicate poor prognosis in patients with early rheumatoid arthritis treated with "sawtooth" strategy. Ann Rheum Dis 1998, 57:533-539.

82. Vittecoq O, Pouplin S, Krzanowska K, Jouen-Beades F, Menard JF, Gayet A, Daragon A, Tron F, Le Loet X: Rheumatoid factor is the strongest predictor of radiological progression of rheumatoid arthritis in a threeyear prospective study in community-recruited patients. Rheumatology (Oxford) 2003, 42:939-946.

83. Bukhari M, Lunt M, Harrison BJ, Scott DG, Symmons DP, Silman AJ: Rheumatoid factor is the major predictor of increasing severity of radiographic erosions in rheumatoid arthritis: results from the Norfolk Arthritis Register Study, a large inception cohort. Arthritis Rheum 2002, 46:906-912.

84. da Mota LM, Dos Santos Neto LL, de Carvalho JF, Pereira IA, Burlingame R, Menard HA, Laurindo IM: The presence of anti-citrullinated protein antibodies (ACPA) and rheumatoid factor on patients with rheumatoid arthritis (RA) does not interfere with the chance of clinical remission in a follow-up of 3 years. Rheumatol Int 2012, 32:3807-3812.

85. Morgan C, Lunt M, Brightwell H, Bradburn P, Fallow W, Lay M, Silman A, Bruce IN: Contribution of patient related differences to multidrug resistance in rheumatoid arthritis. Ann Rheum Dis 2003, 62:15-19.

86. Eberhardt K, Fex E: Clinical course and remission rate in patients with early rheumatoid arthritis: relationship to outcome after 5 years. $\mathrm{Br} J$ Rheumatol 1998, 37:1324-1329.

87. Forslind K, Hafstrom I, Ahlmen M, Svensson B: Sex: a major predictor of remission in early rheumatoid arthritis? Ann Rheum Dis 2007, 66:46-52.

88. Pease CT, Bhakta BB, Devlin J, Emery P: Does the age of onset of rheumatoid arthritis influence phenotype?: a prospective study of outcome and prognostic factors. Rheumatology (Oxford) 1999, 38:228-234

89. Bas S, Genevay S, Meyer O, Gabay C: Anti-cyclic citrullinated peptide antibodies, IgM and IgA rheumatoid factors in the diagnosis and prognosis of rheumatoid arthritis. Rheumatology (Oxford) 2003, 42:677-680.

90. van Venrooij WJ, van Beers JJ, Pruijn GJ: Anti-CCP antibody, a marker for the early detection of rheumatoid arthritis. Ann N Y Acad Sci 2008, 1143:268-285.

91. Mutlu N, Bicakcigil M, Tasan DA, Kaya A, Yavuz S, Ozden Al: Comparative performance analysis of 4 different anti-citrullinated protein assays in the diagnosis of rheumatoid arthritis. J Rheumatol 2009, 36:491-500.

92. Schellekens GA, Visser H, de Jong BA, van den Hoogen FH, Hazes JM, Breedveld FC, van Venrooij WJ: The diagnostic properties of rheumatoid arthritis antibodies recognizing a cyclic citrullinated peptide. Arthritis Rheum 2000, 43:155-163.

93. Balsa A, Del Amo J, Blanco F, Caliz R, Silva L, Sanmarti R, Martinez FG, Tejedor D, Artieda M, Pascual-Salcedo D, Oreiro N, Collado MD, Andreu JL, Graell E, Simon L, Martinez A, Mulero J: Prediction of functional impairment and remission in rheumatoid arthritis patients by biochemical variables and genetic polymorphisms. Rheumatology (Oxford) 2010, 49:458-466.

94. Shidara K, Inoue E, Hoshi D, Sato E, Nakajima A, Momohara S, Taniguchi A, Yamanaka $\mathrm{H}$ : Anti-cyclic citrullinated peptide antibody predicts functional disability in patients with rheumatoid arthritis in a large prospective observational cohort in Japan. Rheumatol Int 2012, 32:361-366.

95. Ronnelid J, Wick MC, Lampa J, Lindblad S, Nordmark B, Klareskog L, van Vollenhoven RF: Longitudinal analysis of citrullinated protein/peptide antibodies (anti-CP) during 5 year follow up in early rheumatoid arthritis: anti-CP status predicts worse disease activity and greater radiological progression. Ann Rheum Dis 2005, 64:1744-1749.

96. del Val del Amo N, Ibanez Bosch R, Fito Manteca C, Gutierrez Polo R, Loza Cortina E: Anti-cyclic citrullinated peptide antibody in rheumatoid arthritis: relation with disease aggressiveness. Clin Exp Rheumatol 2006, 24:281-286.

97. Hetland ML, Stengaard-Pedersen K, Junker P, Ostergaard M, Ejbjerg BJ Jacobsen S, Lottenburger T, Hansen I, Tarp U, Andersen LS, Svendsen A, Pedersen JK, Lauridsen UB, Ellingsen T, Lindegaard H, Podenphant J, Vestergaard A, Jurik AG, Horslev-Petersen K: Radiographic progression and remission rates in early rheumatoid arthritis - MRI bone oedema and anti-CCP predicted radiographic progression in the 5-year extension of the double-blind randomised CIMESTRA trial. Ann Rheum Dis 2010, 69:1789-1795.

98. Syversen SW, Goll GL, van der Heijde D, Landewe R, Lie BA, Odegard S, Uhlig T, Gaarder PI, Kvien TK: Prediction of radiographic progression in rheumatoid arthritis and the role of antibodies against mutated citrullinated vimentin: results from a 10-year prospective study. Ann Rheum Dis 2010, 69:345-351.

99. Nishimura K, Sugiyama D, Kogata Y, Tsuji G, Nakazawa T, Kawano S, Saigo K, Morinobu A, Koshiba M, Kuntz KM, Kamae I, Kumagai S: Meta-analysis: diagnostic accuracy of anti-cyclic citrullinated peptide antibody and rheumatoid factor for rheumatoid arthritis. Ann Intern Med 2007, 146:797-808.

100. Kroot EJ, de Jong BA, van Leeuwen MA, Swinkels $H$, van den Hoogen $F H$, van't Hof M, van de Putte LB, van Rijswijk MH, van Venrooij WJ, van Riel PL: The prognostic value of anti-cyclic citrullinated peptide antibody in patients with recent-onset rheumatoid arthritis. Arthritis Rheum 2000, 43:1831-1835.

101. Meyer O, Labarre C, Dougados M, Goupille P, Cantagrel A, Dubois A, Nicaise-Roland P, Sibilia J, Combe B: Anticitrullinated protein/peptide 
antibody assays in early rheumatoid arthritis for predicting five year radiographic damage. Ann Rheum Dis 2003, 62:120-126.

102. Forslind K, Ahlmen M, Eberhardt K, Hafstrom I, Svensson B: Prediction of radiological outcome in early rheumatoid arthritis in clinical practice: role of antibodies to citrullinated peptides (anti-CCP). Ann Rheum Dis 2004, 63:1090-1095.

103. Sanmarti R, Gomez-Centeno A, Ercilla G, Larrosa M, Vinas O, Vazquez I, Gomez-Puerta JA, Gratacos J, Salvador G, Canete JD: Prognostic factors of radiographic progression in early rheumatoid arthritis: a two year prospective study after a structured therapeutic strategy using DMARDs and very low doses of glucocorticoids. Clin Rheumatol 2007, 26:1111-1118.

104. van der Helm-van Mil AH, Verpoort KN, Breedveld FC, Toes RE, Huizinga TW: Antibodies to citrullinated proteins and differences in clinical progression of rheumatoid arthritis. Arthritis Res Ther 2005, 7:R949-958.

105. Berglin E, Johansson T, Sundin U, Jidell E, Wadell G, Hallmans G, RantapaaDahlqvist $\mathrm{S}$ : Radiological outcome in rheumatoid arthritis is predicted by presence of antibodies against cyclic citrullinated peptide before and at disease onset, and by IgA-RF at disease onset. Ann Rheum Dis 2006, 65:453-458.

106. van der Helm-van Mil AH, le Cessie S, van Dongen H, Breedveld FC, Toes RE, Huizinga TW: A prediction rule for disease outcome in patients with recent-onset undifferentiated arthritis: how to guide individual treatment decisions. Arthritis Rheum 2007, 56:433-440.

107. Cao Y, Bonner A, Barra LJ, Thorne JC, Haraoui B, Boire B, Hitchon CA, Le Riche NGH, Thompson AE, Keystone E, Bykerk V, Pope JE, CATCH Investigators: Response to second-line DMARDs and TNFi in seropositive and seronegative patients in early and late rheumatoid arthritis are not the same: results from the CATCH cohort and a large, established rheumatoid arthritis database [abstract]. Arthritis Rheum 2011, 63(Suppl 10):2202.

108. Verschueren P, Esselens G, Westhovens R: Predictors of remission, normalized physical function, and changes in the working situation during follow-up of patients with early rheumatoid arthritis: an observational study. Scand I Rheumatol 2009, 38:166-172.

109. Boire G, Cossette P, de Brum-Fernandes AJ, Liang P, Niyonsenga T, Zhou ZJ, Carrier N, Daniel C, Menard HA: Anti-Sa antibodies and antibodies against cyclic citrullinated peptide are not equivalent as predictors of severe outcomes in patients with recent-onset polyarthritis. Arthritis Res Ther 2005, 7:R592-603.

110. van den Broek M, Dirven L, Klarenbeek NB, Molenaar TH, Han KH, Kerstens PJ, Huizinga TW, Dijkmans BA, Allaart CF: The association of treatment response and joint damage with ACPA-status in recent-onset RA: a subanalysis of the 8-year follow-up of the BeSt study. Ann Rheum Dis 2012, 71:245-248.

111. van der Woude D, Young A, Jayakumar K, Mertens BJ, Toes RE, van der Heijde D, Huizinga TW, van der Helm-van Mil AH: Prevalence of and predictive factors for sustained disease-modifying antirheumatic drugfree remission in rheumatoid arthritis: results from two large early arthritis cohorts. Arthritis Rheum 2009, 60:2262-2271.

112. Mori S, Hirose J, Yonemura K: Contribution of HLA-DRB1*04 alleles and anti-cyclic citrullinated antibodies to development of resistance to disease-modifying antirheumatic drugs in early rheumatoid arthritis. Clin Rheumatol 2010, 29:1357-1366.

113. Verstappen SM, Lunt M, Bunn DK, Scott DG, Symmons DP: In patients with early inflammatory polyarthritis, ACPA positivity, younger age and inefficacy of the first non-biological DMARD are predictors for receiving biological therapy: results from the Norfolk Arthritis Register. Ann Rheum Dis 2011, 70:1428-1432

114. Kastbom A, Strandberg G, Lindroos A, Skogh T: Anti-CCP antibody test predicts the disease course during 3 years in early rheumatoid arthritis (the Swedish TIRA project). Ann Rheum Dis 2004, 63:1085-1089.

115. van Dongen $H$, van Aken J, Lard LR, Visser K, Ronday HK, Hulsmans HM, Speyer I, Westedt ML, Peeters AJ, Allaart CF, Toes RE, Breedveld FC, Huizinga TW: Efficacy of methotrexate treatment in patients with probable rheumatoid arthritis: a double-blind, randomized, placebocontrolled trial. Arthritis Rheum 2007, 56:1424-1432.

116. Visser K, Verpoort KN, van Dongen $H$, van der Kooij SM, Allaart CF, Toes RE, Huizinga TW, van der Helm-van Mil AH: Pretreatment serum levels of anticyclic citrullinated peptide antibodies are associated with the response to methotrexate in recent-onset arthritis. Ann Rheum Dis 2008, 67:1194-1195.
117. Bang H, Egerer K, Gauliard A, Luthke K, Rudolph PE, Fredenhagen G, Berg W, Feist $E$, Burmester GR: Mutation and citrullination modifies vimentin to a novel autoantigen for rheumatoid arthritis. Arthritis Rheum 2007, 56:2503-2511.

118. Puszczewicz M, Iwaszkiewicz C: Role of anti-citrullinated protein antibodies in diagnosis and prognosis of rheumatoid arthritis. Arch Med Sci 2011, 7:189-194.

119. Dejaco C, Klotz W, Larcher H, Duftner C, Schirmer M, Herold M: Diagnostic value of antibodies against a modified citrullinated vimentin in rheumatoid arthritis. Arthritis Res Ther 2006, 8:R119.

120. Mathsson L, Mullazehi M, Wick MC, Sjoberg O, van Vollenhoven R, Klareskog L, Ronnelid J: Antibodies against citrullinated vimentin in rheumatoid arthritis: higher sensitivity and extended prognostic value concerning future radiographic progression as compared with antibodies against cyclic citrullinated peptides. Arthritis Rheum 2008, 58:36-45.

121. Poulsom $H$, Charles PJ: Antibodies to citrullinated vimentin are a specific and sensitive marker for the diagnosis of rheumatoid arthritis. Clin Rev Allergy Immunol 2008, 34:4-10.

122. Damjanovska L, Thabet MM, Levarth EW, Stoeken-Rijsbergen G, van der Voort El, Toes RE, Huizinga TW, van der Helm-van Mil AH: Diagnostic value of anti-MCV antibodies in differentiating early inflammatory arthritis. Ann Rheum Dis 2010, 69:730-732.

123. Innala L, Kokkonen H, Eriksson C, Jidell E, Berglin E, Dahlqust SR: Antibodies against mutated citrullinated vimentin are a better predictor of disease activity at 24 months in early rheumatoid arthritis than antibodies against cyclic citrullinated peptides. J Rheumatol 2008, 35:1002-1008.

124. Wagner E, Skoumal M, Bayer PM, Klaushofer K: Antibody against mutated citrullinated vimentin: a new sensitive marker in the diagnosis of rheumatoid arthritis. Rheumatol Int 2009, 29:1315-1321.

125. Luime JJ, Colin EM, Hazes JM, Lubberts E: Does anti-mutated citrullinated vimentin have additional value as a serological marker in the diagnostic and prognostic investigation of patients with rheumatoid arthritis? A systematic review. Ann Rheum Dis 2010, 69:337-344.

126. Sizova L: Diagnostic value of antibodies to modified citrullinated vimentin in early rheumatoid arthritis. Hum Immunol 2012, 73:389-392.

127. Raza K, Mathsson L, Buckley CD, Filer A, Ronnelid J: Anti-modified citrullinated vimentin (MCV) antibodies in patients with very early synovitis. Ann Rheum Dis 2010, 69:627-628.

128. Ursum J, Nielen MM, van Schaardenburg D, van der Horst AR, van de Stadt RJ, Dijkmans BA, Hamann D: Antibodies to mutated citrullinated vimentin and disease activity score in early arthritis: a cohort study. Arthritis Res Ther 2008, 10:R12.

129. Raj DS: Role of interleukin-6 in the anemia of chronic disease. Semin Arthritis Rheum 2009, 38:382-388.

130. Furst DE, Chang H, Greenberg JD, Ranganath VK, Reed G, Ozturk ZE, Kremer JM: Prevalence of low hemoglobin levels and associations with other disease parameters in rheumatoid arthritis patients: evidence from the CORRONA registry. Clin Exp Rheumatol 2009, 27:560-566.

131. Mclnnes IB, Schett $\mathrm{G}$ : The pathogenesis of rheumatoid arthritis. N Engl J Med 2011, 365:2205-2219.

132. Gerards AH, de Lathouder S, de Groot ER, Dijkmans BA, Aarden LA: Inhibition of cytokine production by methotrexate. Studies in healthy volunteers and patients with rheumatoid arthritis. Rheumatology (Oxford) 2003, 42:1189-1196.

133. Aggarwal A, Misra R: Methotrexate inhibits interleukin-6 production in patients with juvenile rheumatoid arthritis. Rheumatol Int 2003, 23:134-137.

134. Seitz M, Zwicker M, Villiger PM: Pretreatment cytokine profiles of peripheral blood mononuclear cells and serum from patients with rheumatoid arthritis in different american college of rheumatology response groups to methotrexate. J Rheumatol 2003, 30:28-35.

135. Seitz M, Zwicker M, Wider B: Enhanced in vitro induced production of interleukin 10 by peripheral blood mononuclear cells in rheumatoid arthritis is associated with clinical response to methotrexate treatment. Rheumatol 2001, 28:496-501.

136. Rudwaleit M, Yin Z, Siegert S, Grolms M, Radbruch A, Braun J, Sieper J: Response to methotrexate in early rheumatoid arthritis is associated with a decrease of $T$ cell derived tumour necrosis factor alpha, increase of interleukin 10, and predicted by the initial concentration of interleukin 4. Ann Rheum Dis 2000, 59:311-314. 
137. van der Graaff WL, Prins AP, Dijkmans BA, van Lier RA: Prognostic value of Th1/Th2 ratio in rheumatoid arthritis. Lancet 1998, 351:1931

138. Kuuliala A, Leirisalo-Repo M, Mottonen T, Hannonen P, Nissila M, Kautiainen $\mathrm{H}$, Korpela M, Julkunen $\mathrm{H}$, Hakola M, Repo $\mathrm{H}$ : Serum soluble interleukin-2 receptor predicts early remission in patients with recentonset rheumatoid arthritis treated with a single disease-modifying antirheumatic drug. Clin Exp Rheumatol 2005, 23:243-246.

139. Polisson RP, Dooley MA, Dawson DV, Pisetsky DS: Interleukin-2 receptor levels in the sera of rheumatoid arthritis patients treated with methotrexate. Arthritis Rheum 1994, 37:50-56.

140. Merkel PA, Dooley MA, Dawson DV, Pisetsky DS, Polisson RP: Interleukin-2 receptor levels in sera of patients with rheumatoid arthritis treated with sulfasalazine, parenteral gold, or placebo. J Rheumatol 1996, 23:1856-1861.

141. Gerli R, Bistoni O, Lunardi C, Giacomelli R, Tomassini C, Biagini P, Pitzalis C: Soluble CD30 in early rheumatoid arthritis as a predictor of good response to second-line therapy. Rheumatology (Oxford) 1999, 38:1282-1284.

142. Savolainen E, Matinlauri I, Kautiainen H, Luosujarvi R, KaipiainenSeppanen O: Serum soluble CD30 in early arthritis: a sign of inflammation but not a predictor of outcome. Clin Exp Rheumatol 2008, 26:922-925.

143. Haroon N, Srivastava R, Misra R, Aggarwal A: A novel predictor of clinical response to methotrexate in patients with rheumatoid arthritis: a pilot study of in vitro T cell cytokine suppression. J Rheumatol 2008, 35:975-978,

144. Ercan A, Cui J, Hazen MM, Batliwalla F, Royle L, Rudd PM, Coblyn JS, Shadick N, Weinblatt ME, Gregersen P, Lee DM, Nigrovic PA: Hypogalactosylation of serum $\mathrm{N}$-glycans fails to predict clinical response to methotrexate and TNF inhibition in rheumatoid arthritis. Arthritis Res Ther 2012, 14:R43.

145. Posthumus MD, Limburg PC, Westra J, van Leeuwen MA, van Rijswijk MH: Serum matrix metalloproteinase 3 levels during treatment with sulfasalazine or combination of methotrexate and sulfasalazine in patients with early rheumatoid arthritis. J Rheumatol 2002, 29:883-889.

146. Ribbens C, Andre B, Jaspar JM, Kaye O, Kaiser MJ, De Groote D, Malaise MG: Matrix metalloproteinase-3 serum levels are correlated with disease activity and predict clinical response in rheumatoid arthritis. J Rheumatol 2000, 27:888-893.

147. Baggott JE, Morgan SL: Methotrexate catabolism to 7hydroxymethotrexate in rheumatoid arthritis alters drug efficacy and retention and is reduced by folic acid supplementation. Arthritis Rheum 2009, 60:2257-2261.

148. Baggott JE, Vaughn WH, Hudson BB: Inhibition of 5-aminoimidazole-4carboxamide ribotide transformylase, adenosine deaminase and 5'adenylate deaminase by polyglutamates of methotrexate and oxidized folates and by 5 -aminoimidazole-4-carboxamide riboside and ribotide. Biochem J 1986, 236:193-200.

149. Dervieux T, Furst D, Lein DO, Capps R, Smith K, Caldwell J, Kremer J: Pharmacogenetic and metabolite measurements are associated with clinical status in patients with rheumatoid arthritis treated with methotrexate: results of a multicentred cross sectional observational study. Ann Rheum Dis 2005, 64:1180-1185.

150. Dervieux T, Greenstein N, Kremer J: Pharmacogenomic and metabolic biomarkers in the folate pathway and their association with methotrexate effects during dosage escalation in rheumatoid arthritis. Arthritis Rheum 2006, 54:3095-3103.

151. Hobl EL, Jilma B, Erlacher L, Duhm B, Mustak M, Broll H, Hogger P, Rizovski B, Mader RM: A short-chain methotrexate polyglutamate as outcome parameter in rheumatoid arthritis patients receiving methotrexate. Clin Exp Rheumatol 2012, 30:156-163.

152. Kato T, Hamada A, Mori S, Saito H: Genetic polymorphisms in metabolic and cellular transport pathway of methotrexate impact clinical outcome of methotrexate monotherapy in Japanese patients with rheumatoid arthritis. Drug Metab Pharmacokinet 2012, 27:192-199.

153. Pettit AR, Weedon H, Ahern M, Zehntner S, Frazer IH, Slavotinek J, Au V, Smith MD, Thomas R: Association of clinical, radiological and synovial immunopathological responses to anti-rheumatic treatment in rheumatoid arthritis. Rheumatology (Oxford) 2001, 40:1243-1255.

154. Gregersen PK, Silver J, Winchester RJ: The shared epitope hypothesis. An approach to understanding the molecular genetics of susceptibility to rheumatoid arthritis. Arthritis Rheum 1987, 30:1205-1213.
155. Winchester R, Dwyer E, Rose S: The genetic basis of rheumatoid arthritis. The shared epitope hypothesis. Rheum Dis Clin North Am 1992, 18:761-783.

156. Moxley G, Cohen HJ: Genetic studies, clinical heterogeneity, and disease outcome studies in rheumatoid arthritis. Rheum Dis Clin North Am 2002, 28:39-58.

157. Gorman JD, Criswell LA: The shared epitope and severity of rheumatoid arthritis. Rheum Dis Clin North Am 2002, 28:59-78.

158. Weyand CM, Hicok KC, Conn DL, Goronzy JJ: The influence of HLA-DRB1 genes on disease severity in rheumatoid arthritis. Ann Intern Med 1992, 117:801-806.

159. Goronzy JJ, Matteson EL, Fulbright JW, Warrington KJ, Chang-Miller A, Hunder GG, Mason TG, Nelson AM, Valente RM, Crowson CS, Erlich HA, Reynolds RL, Swee RG, O'Fallon WM, Weyand CM: Prognostic markers of radiographic progression in early rheumatoid arthritis. Arthritis Rheum 2004, 50:43-54.

160. Ferraccioli GF, Gremese E, Tomietto P, Favret G, Damato R, Di Poi E: Analysis of improvements, full responses, remission and toxicity in rheumatoid patients treated with step-up combination therapy (methotrexate, cyclosporin A, sulphasalazine) or monotherapy for three years. Rheumatology (Oxford) 2002, 41:892-898.

161. Gonzalez-Gay MA, Hajeer AH, Garcia-Porrua C, Dababneh A, Thomson W, Ollier WE, Mattey DL: Patients chosen for treatment with cyclosporine because of severe rheumatoid arthritis are more likely to carry HLADRB1 shared epitope alleles, and have earlier disease onset. J Rheumatol 2002, 29:271-275.

162. Ali AA, Moatter T, Baig JA, lqbal A, Hussain A, Iqbal MP: Polymorphism of HLA-DR and HLA-DQ in rheumatoid arthritis patients and clinical response to methotrexate-a hospital-based study. J Pak Med Assoc 2006, 56:452-456.

163. Molenaar ET, Voskuyl AE, van der Horst-Bruinsma IE, Schreuder GM, Zanelli E, Dijkmans BA: Influence of HLA polymorphism on persistent remission in rheumatoid arthritis. Ann Rheum Dis 2002, 61:351-353.

164. Saruhan-Direskeneli G, Inanc M, Fresko I, Akkoc N, Dalkilic E, Erken E, Karaaslan Y, Kinikli G, Oksel F, Pay S, Yucel E, Yentur SP, Duymaz-Tozkir J, Yilmaz V, Inanc N, Yazici H, Konice M, Direskeneli H: The role of HLA-DRB1 shared epitope alleles in predicting short-term response to leflunomide in rheumatoid arthritis. Rheumatology (Oxford) 2007, 46:1842-1844.

165. Dervieux T, Lein DO, Park G, Barham R, Smith K, Walsh M: Single nucleotide polymorphisms (SNPs) in the folate/purine synthesis pathway predict methotrexate's effects in rhematoid arthritis. Arthritis Rheum 2003, 48(Suppl 9):S438.

166. James HM, Gillis D, Hissaria P, Lester S, Somogyi AA, Cleland LG, Proudman SM: Common polymorphisms in the folate pathway predict efficacy of combination regimens containing methotrexate and sulfasalazine in early rheumatoid arthritis. J Rheumatol 2008, 35:562-571.

167. Drozdzik M, Rudas T, Pawlik A, Gornik W, Kurzawski M, Herczynska M: Reduced folate carrier-1 $80 \mathrm{G}>\mathrm{A}$ polymorphism affects methotrexate treatment outcome in rheumatoid arthritis. Pharmacogenomics J 2007, 7:404-407.

168. Dervieux T, Kremer J, Lein DO, Capps R, Barham R, Meyer G, Smith K, Caldwell J, Furst DE: Contribution of common polymorphisms in reduced folate carrier and gamma-glutamylhydrolase to methotrexate polyglutamate levels in patients with rheumatoid arthritis. Pharmacogenetics 2004, 14:733-739.

169. Laverdiere C, Chiasson S, Costea I, Moghrabi A, Krajinovic M: Polymorphism $\mathrm{G} 80 \mathrm{~A}$ in the reduced folate carrier gene and its relationship to methotrexate plasma levels and outcome of childhood acute lymphoblastic leukemia. Blood 2002, 100:3832-3834.

170. Baslund B, Gregers J, Nielsen CH: Reduced folate carrier polymorphism determines methotrexate uptake by B cells and CD4+ T cells. Rheumatology (Oxford) 2008, 47:451-453.

171. Wessels JA, de Vries-Bouwstra JK, Heijmans BT, Slagboom PE, GoekoopRuiterman YP, Allaart CF, Kerstens PJ, van Zeben D, Breedveld FC, Dijkmans BA, Huizinga TW, Guchelaar HJ: Efficacy and toxicity of methotrexate in early rheumatoid arthritis are associated with singlenucleotide polymorphisms in genes coding for folate pathway enzymes. Arthritis Rheum 2006, 54:1087-1095.

172. Takatori R, Takahashi KA, Tokunaga D, Hojo T, Fujioka M, Asano T, Hirata T, Kawahito Y, Satomi Y, Nishino H, Tanaka T, Hirota Y, Kubo T: ABCB1 C3435T 
polymorphism influences methotrexate sensitivity in rheumatoid arthritis patients. Clin Exp Rheumatol 2006, 24:546-554.

173. Owen SA, Hider SL, Martin P, Bruce IN, Barton A, Thomson W: Genetic polymorphisms in key methotrexate pathway genes are associated with response to treatment in rheumatoid arthritis patients. Pharmacogenomics J 2012, doi: 10.1038/tpj.2012.7.

174. Stamp LK, Roberts RL: Effect of genetic polymorphisms in the folate pathway on methotrexate therapy in rheumatic diseases. Pharmacogenomics 2011, 12:1449-1463.

175. van der Heijden JW, Dijkmans BA, Scheper RJ, Jansen G: Drug Insight: resistance to methotrexate and other disease-modifying antirheumatic drugs-from bench to bedside. Nat Clin Pract Rheumatol 2007, 3:26-34.

176. Ranganathan P: An update on methotrexate pharmacogenetics in rheumatoid arthritis. Pharmacogenomics 2008, 9:439-451.

177. Pawlik A, Wrzesniewska J, Fiedorowicz-Fabrycy I, Gawronska-Szklarz B: The MDR1 3435 polymorphism in patients with rheumatoid arthritis. Int J Clin Pharmacol Ther 2004, 42:496-503.

178. Drozdzik M, Rudas T, Pawlik A, Kurzawski M, Czerny B, Gornik W, Herczynska M: The effect of 3435C>T MDR1 gene polymorphism on rheumatoid arthritis treatment with disease-modifying antirheumatic drugs. Eur J Clin Pharmacol 2006, 62:933-937.

179. Bohanec Grabar P, Logar D, Lestan B, Dolzan V: Genetic determinants of methotrexate toxicity in rheumatoid arthritis patients: a study of polymorphisms affecting methotrexate transport and folate metabolism. Eur J Clin Pharmacol 2008, 64:1057-1068.

180. Kooloos WM, Wessels JA, van der Straaten T, Allaart CF, Huizinga TW, Guchelaar HJ: Functional polymorphisms and methotrexate treatment outcome in recent-onset rheumatoid arthritis. Pharmacogenomics 2010, 11:163-175

181. Ranganathan P, Culverhouse R, Marsh S, Ahluwalia R, Shannon WD, Eisen S, McLeod $\mathrm{HL}$ : Single nucleotide polymorphism profiling across the methotrexate pathway in normal subjects and patients with rheumatoid arthritis. Pharmacogenomics 2004, 5:559-569.

182. Warren RB, Smith RL, Campalani E, Eyre S, Smith CH, Barker JN, Worthington J, Griffiths CE: Genetic variation in efflux transporters influences outcome to methotrexate therapy in patients with psoriasis. $J$ Invest Dermatol 2008, 128:1925-1929.

183. Cheng Q, Wu B, Kager L, Panetta JC, Zheng J, Pui CH, Relling MV, Evans WE: A substrate specific functional polymorphism of human gammaglutamyl hydrolase alters catalytic activity and methotrexate polyglutamate accumulation in acute lymphoblastic leukaemia cells. Pharmacogenetics 2004, 14:557-567.

184. van der Straaten RJ, Wessels JA, de Vries-Bouwstra JK, GoekoopRuiterman YP, Allaart CF, Bogaartz J, Tiller M, Huizinga TW, Guchelaar HJ: Exploratory analysis of four polymorphisms in human GGH and FPGS genes and their effect in methotrexate-treated rheumatoid arthritis patients. Pharmacogenomics 2007, 8:141-150.

185. Sharma S, Das M, Kumar A, Marwaha V, Shankar S, Singh P, Raghu P, Aneja R, Grover R, Arya V, Dhir V, Gupta R, Kumar U, Juyal RC, Thelma BK: Purine biosynthetic pathway genes and methotrexate response in rheumatoid arthritis patients among north Indians. Pharmacogenet Genomics 2009, 19:823-828

186. Horie N, Aiba H, Oguro K, Hojo H, Takeishi K: Functional analysis and DNA polymorphism of the tandemly repeated sequences in the $5^{\prime}$-terminal regulatory region of the human gene for thymidylate synthase. Cell Struct Funct 1995, 20:191-197.

187. Dervieux T, Furst D, Lein DO, Capps R, Smith K, Walsh M, Kremer J: Polyglutamation of methotrexate with common polymorphisms in reduced folate carrier, aminoimidazole carboxamide ribonucleotide transformylase, and thymidylate synthase are associated with methotrexate effects in rheumatoid arthritis. Arthritis Rheum 2004, 50:2766-2774.

188. Kumagai K, Hiyama K, Oyama T, Maeda H, Kohno N: Polymorphisms in the thymidylate synthase and methylenetetrahydrofolate reductase genes and sensitivity to the low-dose methotrexate therapy in patients with rheumatoid arthritis. Int J Mol Med 2003, 11:593-600.

189. Inoue S, Hashiguchi M, Takagi K, Kawai S, Mochizuki M: Preliminary study to identify the predictive factors for the response to methotrexate therapy in patients with rheumatoid arthritis. Yakugaku Zasshi 2009, 129:843-849

190. Ulrich CM, Bigler J, Velicer CM, Greene EA, Farin FM, Potter JD: Searching expressed sequence tag databases: discovery and confirmation of a common polymorphism in the thymidylate synthase gene. Cancer Epidemiol Biomarkers Prev 2000, 9:1381-1385.

191. Mandola MV, Stoehlmacher J, Zhang W, Groshen S, Yu MC, Iqbal S, Lenz HJ, Ladner RD: A 6 bp polymorphism in the thymidylate synthase gene causes message instability and is associated with decreased intratumoral TS mRNA levels. Pharmacogenetics 2004, 14:319-327.

192. Banerjee D, Mayer-Kuckuk P, Capiaux G, Budak-Alpdogan T, Gorlick R, Bertino JR: Novel aspects of resistance to drugs targeted to dihydrofolate reductase and thymidylate synthase. Biochim Biophys Acta 2002, 1587:164-173.

193. Goto Y, Yue L, Yokoi A, Nishimura R, Uehara T, Koizumi S, Saikawa Y: A novel single-nucleotide polymorphism in the 3 '-untranslated region of the human dihydrofolate reductase gene with enhanced expression. Clin Cancer Res 2001, 7:1952-1956.

194. Milic V, Jekic B, Lukovic L, Bunjevacki V, Milasin J, Novakovic I, Damnjanovic T, Popovic B, Maksimovic N, Damjanov N, Radunovic G, Pejnovic N, Krajinovic M: Association of dihydrofolate reductase (DHFR) -317AA genotype with poor response to methotrexate in patients with rheumatoid arthritis. Clin Exp Rheumatol 2012, 30:178-183.

195. Lee YC, Cui J, Costenbader KH, Shadick NA, Weinblatt ME, Karlson EW: Investigation of candidate polymorphisms and disease activity in rheumatoid arthritis patients on methotrexate. Rheumatology (Oxford) 2009, 48:613-617.

196. Wessels JA, Kooloos WM, De Jonge R, De Vries-Bouwstra JK, Allaart CF, Linssen A, Collee G, De Sonnaville P, Lindemans J, Huizinga TW, Guchelaar HJ: Relationship between genetic variants in the adenosine pathway and outcome of methotrexate treatment in patients with recent-onset rheumatoid arthritis. Arthritis Rheum 2006, 54:2830-2839.

197. Hinks A, Moncrieffe H, Martin P, Ursu S, Lal S, Kassoumeri L, Weiler T, Glass DN, Thompson SD, Wedderburn LR, Thomson W: Association of the 5-aminoimidazole-4-carboxamide ribonucleotide transformylase gene with response to methotrexate in juvenile idiopathic arthritis. Ann Rheum Dis 2011, 70:1395-1400.

198. van Ede AE, Laan RF, Blom HJ, Huizinga TW, Haagsma CJ, Giesendorf BA, de Boo TM, van de Putte LB: The C677T mutation in the methylenetetrahydrofolate reductase gene: a genetic risk factor for methotrexate-related elevation of liver enzymes in rheumatoid arthritis patients. Arthritis Rheum 2001, 44:2525-2530.

199. Kang SS, Zhou J, Wong PW, Kowalisyn J, Strokosch G: Intermediate homocysteinemia: a thermolabile variant of methylenetetrahydrofolate reductase. Am J Hum Genet 1988, 43:414-421.

200. Ulrich CM, Robien K, Sparks R: Pharmacogenetics and folate metabolism a promising direction. Pharmacogenomics 2002, 3:299-313.

201. Weisberg I, Tran P, Christensen B, Sibani S, Rozen R: A second genetic polymorphism in methylenetetrahydrofolate reductase (MTHFR) associated with decreased enzyme activity. Mol Genet Metab 1998, 64:169-172.

202. Hider SL, Bruce IN, Thomson W: The pharmacogenetics of methotrexate. Rheumatology (Oxford) 2007, 46:1520-1524.

203. van der Put NM, Gabreels F, Stevens EM, Smeitink JA, Trijbels FJ, Eskes TK, van den Heuvel $L P$, Blom HJ: A second common mutation in the methylenetetrahydrofolate reductase gene: an additional risk factor for neural-tube defects? Am J Hum Genet 1998, 62:1044-1051.

204. Wesoly J, Wessels JA, Guchelaar HJ, Huizinga TW: Genetic markers of treatment response in rheumatoid arthritis. Curr Rheumatol Rep 2006, 8:369-377.

205. Kurzawski M, Pawlik A, Safranow K, Herczynska M, Drozdzik M: 677C>T and 1298A >C MTHFR polymorphisms affect methotrexate treatment outcome in rheumatoid arthritis. Pharmacogenomics 2007, 8:1551-1559.

206. Aggarwal P, Naik S, Mishra KP, Aggarwal A, Misra R: Correlation between methotrexate efficacy \& toxicity with C677T polymorphism of the methylenetetrahydrofolate gene in rheumatoid arthritis patients on folate supplementation. Indian J Med Res 2006, 124:521-526.

207. van Ede AE, Laan RF, Rood MJ, Huizinga TW, van de Laar MA, van Denderen CJ, Westgeest TA, Romme TC, de Rooij DJ, Jacobs MJ, de Boo TM, van der Wilt GJ, Severens JL, Hartman M, Krabbe PF, Dijkmans BA, Breedveld FC, van de Putte LB: Effect of folic or folinic acid supplementation on the toxicity and efficacy of methotrexate in rheumatoid arthritis: a forty-eight week, multicenter, randomized, double-blind, placebo-controlled study. Arthritis Rheum 2001, 44:1515-1524. 
208. Taniguchi A, Urano W, Tanaka E, Furihata S, Kamitsuji S, Inoue E Yamanaka M, Yamanaka H, Kamatani N: Validation of the associations between single nucleotide polymorphisms or haplotypes and responses to disease-modifying antirheumatic drugs in patients with rheumatoid arthritis: a proposal for prospective pharmacogenomic study in clinical practice. Pharmacogenet Genomics 2007, 17:383-390.

209. Urano W, Taniguchi A, Yamanaka H, Tanaka E, Nakajima H, Matsuda Y, Akama H, Kitamura Y, Kamatani N: Polymorphisms in the methylenetetrahydrofolate reductase gene were associated with both the efficacy and the toxicity of methotrexate used for the treatment of rheumatoid arthritis, as evidenced by single locus and haplotype analyses. Pharmacogenetics 2002, 12:183-190.

210. Berkun Y, Levartovsky D, Rubinow A, Orbach H, Aamar S, Grenader T, Abou Atta I, Mevorach D, Friedman G, Ben-Yehuda A: Methotrexate related adverse effects in patients with rheumatoid arthritis are associated with the A1298C polymorphism of the MTHFR gene. Ann Rheum Dis 2004, 63:1227-1231.

211. Hughes LB, Beasley TM, Patel H, Tiwari HK, Morgan SL, Baggott JE, Saag KG, McNicholl J, Moreland LW, Alarcon GS, Bridges SL Jr: Racial or ethnic differences in allele frequencies of single-nucleotide polymorphisms in the methylenetetrahydrofolate reductase gene and their influence on response to methotrexate in rheumatoid arthritis. Ann Rheum Dis 2006, 65:1213-1218.

212. Ghodke Y, Chopra A, Joshi K, Patwardhan B: Are thymidylate synthase and methylene tetrahydrofolate reductase genes linked with methotrexate response (efficacy, toxicity) in Indian (Asian) rheumatoid arthritis patients? Clin Rheumatol 2008, 27:787-789.

213. Owen SA, Lunt M, Bowes J, Hider SL, Bruce IN, Thomson W, Barton A: MTHFR gene polymorphisms and outcome of methotrexate treatment in patients with rheumatoid arthritis: analysis of key polymorphisms and meta-analysis of C677T and A1298C polymorphisms. Pharmacogenomics J 2011, doi: 10.1038/tpj.2011.42.

214. Taraborelli M, Andreoli L, Archetti S, Ferrari M, Cattaneo R, Tincani A: Methylenetetrahydrofolate reductase polymorphisms and methotrexate: no association with response to therapy nor with drug-related adverse events in an Italian population of rheumatic patients. Clin Exp Rheumatol 2009, 27:499-502.

215. Hayashi H, Fujimaki C, Daimon T, Tsuboi S, Matsuyama T, Itoh K: Genetic polymorphisms in folate pathway enzymes as a possible marker for predicting the outcome of methotrexate therapy in Japanese patients with rheumatoid arthritis. J Clin Pharm Ther 2009, 34:355-361.

216. Lee YH, Song GG: Associations between the C677T and A1298C polymorphisms of MTHFR and the efficacy and toxicity of methotrexate in rheumatoid arthritis: a meta-analysis. Clin Drug Investig 2010, 30:101-108.

217. Sharma S, Das M, Kumar A, Marwaha V, Shankar S, Aneja R, Grover R, Arya V, Dhir V, Gupta R, Kumar U, Juyal RC, Thelma BK: Interaction of genes from influx-metabolism-efflux pathway and their influence on methotrexate efficacy in rheumatoid arthritis patients among Indians. Pharmacogenet Genomics 2008, 18:1041-1049.

218. Dervieux T, Wessels JA, van der Straaten T, Penrod N, Moore JH, Guchelaar HJ, Kremer JM: Gene-gene interactions in folate and adenosine biosynthesis pathways affect methotrexate efficacy and tolerability in rheumatoid arthritis. Pharmacogenet Genomics 2009, 19:935-944.

219. Dervieux T, Wessels JA, Kremer JM, Padyukov L, Seddighzadeh M, Saevarsdottir S, van Vollenhoven RF, Klareskog L, Huizinga TW, Guchelaar HJ: Patterns of interaction between genetic and nongenetic attributes and methotrexate efficacy in rheumatoid arthritis. Pharmacogenet Genomics 2012, 22:1-9.

220. Hider SL, Bruce IN, Silman AJ, Symmons DP: Defining response to disease modifying antirheumatic drugs in patients with rheumatoid arthritis. J Rheumatol 2005, 32:6-10.

221. Galivan J: Evidence for the cytotoxic activity of polyglutamate derivatives of methotrexate. Mol Pharmacol 1980, 17:105-110.

222. Hooijberg JH, Broxterman HJ, Kool M, Assaraf YG, Peters GJ, Noordhuis P, Scheper RJ, Borst P, Pinedo HM, Jansen G: Antifolate resistance mediated by the multidrug resistance proteins MRP1 and MRP2. Cancer Res 1999, 59:2532-2535

223. Zeng H, Chen ZS, Belinsky MG, Rea PA, Kruh GD: Transport of methotrexate (MTX) and folates by multidrug resistance protein (MRP) 3 and MRP1: effect of polyglutamylation on MTX transport. Cancer Res 2001, 61:7225-7232.

224. Kool M, van der Linden $M$, de Haas $M$, Scheffer $G L$, de Vree JM, Smith AJ, Jansen G, Peters GJ, Ponne N, Scheper RJ, Elferink RP, Baas F, Borst P: MRP3, an organic anion transporter able to transport anti-cancer drugs. Proc Natl Acad Sci USA 1999, 96:6914-6919.

225. White JC, Goldman ID: Mechanism of action of methotrexate. IV. Free intracellular methotrexate required to suppress dihydrofolate reduction to tetrahydrofolate by Ehrlich ascites tumor cells in vitro. Mol Pharmacol 1976, 12:711-719.

226. Allegra CJ, Chabner BA, Drake JC, Lutz R, Rodbard D, Jolivet J: Enhanced inhibition of thymidylate synthase by methotrexate polyglutamates. $J$ Biol Chem 1985, 260:9720-9726.

227. Szeto DW, Cheng YC, Rosowsky A, Yu CS, Modest EJ, Piper JR, Temple C Jr, Elliott RD, Rose JD, Montgomery JA: Human thymidylate synthetase-III. Effects of methotrexate and folate analogs. Biochem Pharmacol 1979, 28:2633-2637.

228. Allegra CJ, Drake JC, Jolivet J, Chabner BA: Inhibition of phosphoribosylaminoimidazolecarboxamide transformylase by methotrexate and dihydrofolic acid polyglutamates. Proc Natl Acad Sci USA 1985, 82:4881-4885.

229. Chan ES, Cronstein BN: Molecular action of methotrexate in inflammatory diseases. Arthritis Res 2002, 4:266-273.

230. Cronstein BN, Naime D, Ostad E: The antiinflammatory mechanism of methotrexate. Increased adenosine release at inflamed sites diminishes leukocyte accumulation in an in vivo model of inflammation. $J$ Clin Invest 1993, 92:2675-2682.

231. Alarcon GS, Kremer JM, Macaluso M, Weinblatt ME, Cannon GW, Palmer WR St Clair EW, Sundy JS, Alexander RW, Smith GJ, Axiotis CA: Risk factors for methotrexate-induced lung injury in patients with rheumatoid arthritis. A multicenter, case-control study. Methotrexate-Lung Study Group. Ann Intern Med 1997, 127:356-364.

232. Kent PD, Luthra HS, Michet C Jr: Risk factors for methotrexate-induced abnormal laboratory monitoring results in patients with rheumatoid arthritis. J Rheumatol 2004, 31:1727-1731.

233. Walker AM, Funch D, Dreyer NA, Tolman KG, Kremer JM, Alarcon GS, Lee RG, Weinblatt ME: Determinants of serious liver disease among patients receiving low-dose methotrexate for rheumatoid arthritis. Arthritis Rheum 1993, 36:329-335.

234. Beyeler C, Jordi B, Gerber NJ, Im Hof V: Pulmonary function in rheumatoid arthritis treated with low-dose methotrexate: a longitudinal study. $\mathrm{Br} J$ Rheumatol 1996, 35:446-452.

235. Ito S, Nakazono K, Murasawa A, Mita Y, Hata K, Saito N, Kikuchi M, Yoshida K, Nakano M, Gejyo F: Development of fulminant hepatitis B (precore variant mutant type) after the discontinuation of low-dose methotrexate therapy in a rheumatoid arthritis patient. Arthritis Rheum 2001, 44:339-342.

236. Shergy WJ, Polisson RP, Caldwell DS, Rice JR, Pisetsky DS, Allen NB: Methotrexate-associated hepatotoxicity: retrospective analysis of 210 patients with rheumatoid arthritis. Am J Med 1988, 85:771-774.

237. Phillips CA, Cera PJ, Mangan TF, Newman ED: Clinical liver disease in patients with rheumatoid arthritis taking methotrexate. J Rheumatol 1992, 19:229-233.

238. Furst DE, Koehnke $R$, Burmeister LF, Kohler J, Cargill I: Increasing methotrexate effect with increasing dose in the treatment of resistant rheumatoid arthritis. J Rheumatol 1989, 16:313-320.

239. Schnabel A, Reinhold-Keller E, Willmann V, Gross WL: Tolerability of methotrexate starting with 15 or $25 \mathrm{mg} /$ week for rheumatoid arthritis. Rheumatol Int 1994, 14:33-38.

240. Verstappen SM, Jacobs JW, van der Veen MJ, Heurkens AH, Schenk Y, ter Borg EJ, Blaauw AA, Bijlsma JW, Utrecht Rheumatoid Arthritis Cohort study group: Intensive treatment with methotrexate in early rheumatoid arthritis: aiming for remission. Computer Assisted Management in Early Rheumatoid Arthritis (CAMERA, an open-label strategy trial). Ann Rheum Dis 2007, 66:1443-1449.

241. Wegrzyn J, Adeleine $P$, Miossec $P$ : Better efficacy of methotrexate given by intramuscular injection than orally in patients with rheumatoid arthritis. Ann Rheum Dis 2004, 63:1232-1234.

242. Braun J, Kastner P, Flaxenberg P, Wahrisch J, Hanke P, Demary W, von Hinuber U, Rockwitz K, Heitz W, Pichlmeier U, Guimbal-Schmolck C, 
Brandt A, MC-MTX 6/Rh Study Group: Comparison of the clinical efficacy and safety of subcutaneous versus oral administration of methotrexate in patients with active rheumatoid arthritis: results of a six-month, multicenter, randomized, double-blind, controlled, phase IV trial. Arthritis Rheum 2008, 58:73-81.

243. Morgan SL, Baggott JE, Vaughn WH, Young PK, Austin JV, Krumdieck CL, Alarcon GS: The effect of folic acid supplementation on the toxicity of low-dose methotrexate in patients with rheumatoid arthritis. Arthritis Rheum 1990, 33:9-18

244. Morgan SL, Baggott JE, Vaughn WH, Austin JS, Veitch TA, Lee JY, Koopman WJ, Krumdieck CL, Alarcon GS: Supplementation with folic acid during methotrexate therapy for rheumatoid arthritis. A double-blind, placebo-controlled trial. Ann Intern Med 1994, 121:833-841.

245. Shiroky JB, Neville C, Esdaile JM, Choquette D, Zummer M, Hazeltine M, Bykerk V, Kanji M, St-Pierre A, Robidoux L, Bourque L: Low-dose methotrexate with leucovorin (folinic acid) in the management of rheumatoid arthritis. Results of a multicenter randomized, double-blind, placebo-controlled trial. Arthritis Rheum 1993, 36:795-803.

246. Kremer JM, Furst DE, Weinblatt ME, Blotner SD: Significant changes in serum AST across hepatic histological biopsy grades: prospective analysis of 3 cohorts receiving methotrexate therapy for rheumatoid arthritis. J Rheumatol 1996, 23:459-461.

247. Kremer JM, Alarcon GS, Lightfoot RW Jr, Willkens RF, Furst DE, Williams HJ, Dent PB, Weinblatt ME: Methotrexate for rheumatoid arthritis. Suggested guidelines for monitoring liver toxicity. American College of Rheumatology. Arthritis Rheum 1994, 37:316-328.

248. Gutierrez-Urena S, Molina JF, Garcia CO, Cuellar ML, Espinoza LR: Pancytopenia secondary to methotrexate therapy in rheumatoid arthritis. Arthritis Rheum 1996, 39:272-276.

249. Rau R, Karger T, Herborn G, Frenzel H: Liver biopsy findings in patients with rheumatoid arthritis undergoing longterm treatment with methotrexate. J Rheumatol 1989, 16:489-493.

250. Kremer JM, Lee RG, Tolman KG: Liver histology in rheumatoid arthritis patients receiving long-term methotrexate therapy. A prospective study with baseline and sequential biopsy samples. Arthritis Rheum 1989, 32:121-127.

251. Visser K, van der Heijde D: Incidence of liver enzyme elevations and liver biopsy abnormalities during methotrexate treatment in rheumatoid arthritis: a systematic review of the literature. Arthritis Rheum 2008, 58(Suppl):S557.

252. Ros S, Juanola X, Condom E, Canas C, Riera J, Guardiola J, Del Blanco J, Rebasa P, Valverde J, Roig-Escofet O: Light and electron microscopic analysis of liver biopsy samples from rheumatoid arthritis patients receiving long-term methotrexate therapy. Scand J Rheumatol 2002, 31:330-336.

253. Choi HK, Hernan MA, Seeger JD, Robins JM, Wolfe F: Methotrexate and mortality in patients with rheumatoid arthritis: a prospective study. Lancet 2002, 359:1173-1177.

254. van Halm VP, Nurmohamed MT, Twisk JW, Dijkmans BA, Voskuyl AE: Disease-modifying antirheumatic drugs are associated with a reduced risk for cardiovascular disease in patients with rheumatoid arthritis: a case control study. Arthritis Res Ther 2006, 8:R151.

255. Salliot C, van der Heijde D: Long-term safety of methotrexate monotherapy in patients with rheumatoid arthritis: a systematic literature research. Ann Rheum Dis 2009, 68:1100-1104.

256. Doran MF, Crowson CS, Pond GR, O'Fallon WM, Gabriel SE: Predictors of infection in rheumatoid arthritis. Arthritis Rheum 2002, 46:2294-2300.

257. Wolfe F, Michaud K: Lymphoma in rheumatoid arthritis: the effect of methotrexate and anti-tumor necrosis factor therapy in 18,572 patients. Arthritis Rheum 2004, 50:1740-1751.

258. Hoshida Y, Xu JX, Fujita S, Nakamichi I, Ikeda J, Tomita Y, Nakatsuka S, Tamaru J, lizuka A, Takeuchi T, Aozasa K: Lymphoproliferative disorders in rheumatoid arthritis: clinicopathological analysis of 76 cases in relation to methotrexate medication. J Rheumatol 2007, 34:322-331.

259. Katchamart W, Trudeau J, Phumethum V, Bombardier C: Efficacy and toxicity of methotrexate (MTX) monotherapy versus MTX combination therapy with non-biological disease-modifying antirheumatic drugs in rheumatoid arthritis: a systematic review and meta-analysis. Ann Rheum Dis 2009, 68:1105-1112.

260. Tugwell P, Pincus T, Yocum D, Stein M, Gluck O, Kraag G, McKendry R, Tesser J, Baker P, Wells G: Combination therapy with cyclosporine and methotrexate in severe rheumatoid arthritis. The MethotrexateCyclosporine Combination Study Group. N Engl J Med 1995, 333:137-141.

261. Capell HA, Madhok R, Porter DR, Munro RA, Mclnnes IB, Hunter JA, Steven M, Zoma A, Morrison E, Sambrook M, Wui Poon F, Hampson R, McDonald F, Tierney A, Henderson N, Ford I: Combination therapy with sulfasalazine and methotrexate is more effective than either drug alone in patients with rheumatoid arthritis with a suboptimal response to sulfasalazine: results from the double-blind placebo-controlled MASCOT study. Ann Rheum Dis 2007, 66:235-241.

262. Haagsma CJ, van Riel PL, de Jong AJ, van de Putte LB: Combination of sulphasalazine and methotrexate versus the single components in early rheumatoid arthritis: a randomized, controlled, double-blind, 52 week clinical trial. Br J Rheumatol 1997, 36:1082-1088.

263. Dougados M, Combe B, Cantagrel A, Goupille P, Olive P, Schattenkirchner M, Meusser S, Paimela L, Rau R, Zeidler H, LeirisaloRepo M, Peldan K: Combination therapy in early rheumatoid arthritis: a randomised, controlled, double blind 52 week clinical trial of sulphasalazine and methotrexate compared with the single components. Ann Rheum Dis 1999, 58:220-225.

264. Sany J, Anaya JM, Canovas F, Combe B, Jorgensen C, Saker S, Thaury MN, Gavroy JP: Influence of methotrexate on the frequency of postoperative infectious complications in patients with rheumatoid arthritis. $J$ Rheumatol 1993, 20:1129-1132.

265. Murata K, Yasuda T, Ito H, Yoshida M, Shimizu M, Nakamura T: Lack of increase in postoperative complications with low-dose methotrexate therapy in patients with rheumatoid arthritis undergoing elective orthopedic surgery. Mod Rheumatol 2006, 16:14-19.

266. Ostensen M, Hartmann H, Salvesen K: Low dose weekly methotrexate in early pregnancy. A case series and review of the literature. J Rheumatol 2000, 27:1872-1875.

267. Ostensen M, von Esebeck M, Villiger PM: Therapy with immunosuppressive drugs and biological agents and use of contraception in patients with rheumatic disease. J Rheumatol 2007, 34:1266-1269.

268. Lewden B, Vial T, Elefant E, Nelva A, Carlier P, Descotes J, French Network of Regional Pharmacovigilance C: Low dose methotrexate in the first trimester of pregnancy: results of a French collaborative study. $J$ Rheumatol 2004, 31:2360-2365.

269. Oxford Centre for Evidence Based Medicine - Levels of Evidence. [http:// www.cebm.net/index.aspx?o=1025], (accessed March 2008).

\section{Pre-publication history}

The pre-publication history for this paper can be accessed here: http://www.biomedcentral.com/1741-7015/11/17/prepub

\section{doi:10.1186/1741-7015-11-17}

Cite this article as: Romão et al:: Old drugs, old problems: where do we stand in prediction of rheumatoid arthritis responsiveness to methotrexate and other synthetic DMARDs? BMC Medicine 2013 11:17.

\section{Submit your next manuscript to BioMed Central and take full advantage of:}

- Convenient online submission

- Thorough peer review

- No space constraints or color figure charges

- Immediate publication on acceptance

- Inclusion in PubMed, CAS, Scopus and Google Scholar

- Research which is freely available for redistribution 